\title{
Why We Need Sustainable Networks Bridging Countries, Disciplines, Cultures and Generations for Aquatic Biomonitoring 2.0: A Perspective Derived From the DNAqua-Net COST Action
}

Florian Leese ${ }^{*, t, 1}$, Agnès Bouchez ${ }^{\ddagger}$, Kessy Abarenkov ${ }^{\S}$, Florian Altermatt ${ }^{\mathrm{I}, \|}$, Ángel Borja ${ }^{\#}$, Kat Bruce**, Torbjørn Ekrem ${ }^{\dagger \dagger}$, Fedor Čiampor Jr. ${ }^{\neq \neq}$, Zuzana Čiamporová-Zatovičová ${ }^{\neq \neq}$, Filipe O. Costa ${ }^{\S \S}$, Sofia Duarte ${ }^{\S \S}$, Vasco Elbrecht*, IIII, Diego Fontaneto \|\| , Alain Franc ${ }^{\# \#}$, Matthias F. Geiger***, Daniel Hering $^{*,+}$, Maria Kahlert ${ }^{+\dagger+}$, Belma Kalamujić Stroil ${ }^{\neq \neq \ddagger}$, Martyn Kelly ${ }^{\S \S \S}$, Emre Keskin ${ }^{\text {IIIIII, Igor Liska }}{ }^{\|\| \|}$, Patricia Mergen ${ }^{\# \# \#, * * * *}$, Kristian Meissner ${ }^{\dagger++}$, Jan Pawlowski ${ }^{\# \neq \neq}$, Lyubomir Penev $^{\S \S \S \S, \text { Yorick Reyjol IIIIIII , Ana Rotter }}{ }^{|\||||||, ~}$ Dirk Steinke ${ }^{\mathrm{III}, \# \# \# \#, \text { Bas van der Wal }{ }^{* * * * *} \text {, Simon Vitecek }}{ }^{\dagger+++t, \neq \neq \neq \neq \neq}$,

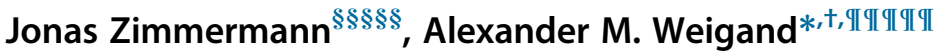

*Aquatic Ecology, University of Duisburg-Essen, Essen, Germany

${ }^{\dagger}$ Center of Water and Environmental Research (ZWU), University of Duisburg-Essen, Essen, Germany ${ }^{\ddagger}$ INRA UMR CARRTEL, Thonon-les-bains, France

${ }^{\S}$ University of Tartu, Tartu, Estonia

${ }^{\text {II }}$ Eawag, Dübendorf, Switzerland

"University of Zurich, Zürich, Switzerland

${ }^{\#}$ AZTI, Pasaia, Spain

**NatureMetrics, CABI Site, Surrey, United Kingdom

${ }^{{ }^{+}}$Norwegian University of Science and Technology, Trondheim, Norway

拉Zoology Lab, Plant Science and Biodiversity Center, Slovak Academy of Sciences, Bratislava, Slovakia

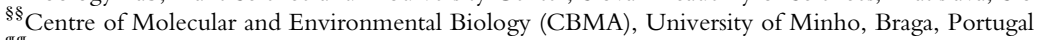

${ }^{\mathbb{I I I} C e n t r e}$ for Biodiversity Genomics, University of Guelph, Guelph, ON, Canada

"I\| National Research Council of Italy, Institute of Ecosystem Study, Verbania Pallanza, Italy

\#\#BIOGECO, INRA, Univ. Bordeaux, Cestas, and Pleiade Team, INRIA Sud-Ouest, Talence, France

***Zoologisches Forschungsmuseum Alexander Koenig, Leibniz Institute for Animal Biodiversity, Bonn, Germany

${ }^{+t+}$ Swedish University of Agricultural Sciences, Uppsala, Sweden

${ }_{\ddagger \ddagger}$ University of Sarajevo-Institute for Genetic Engineering and Biotechnology, Sarajevo, Bosnia and Herzegovina

$\S \S$ Bowburn Consultancy, Durham, United Kingdom 


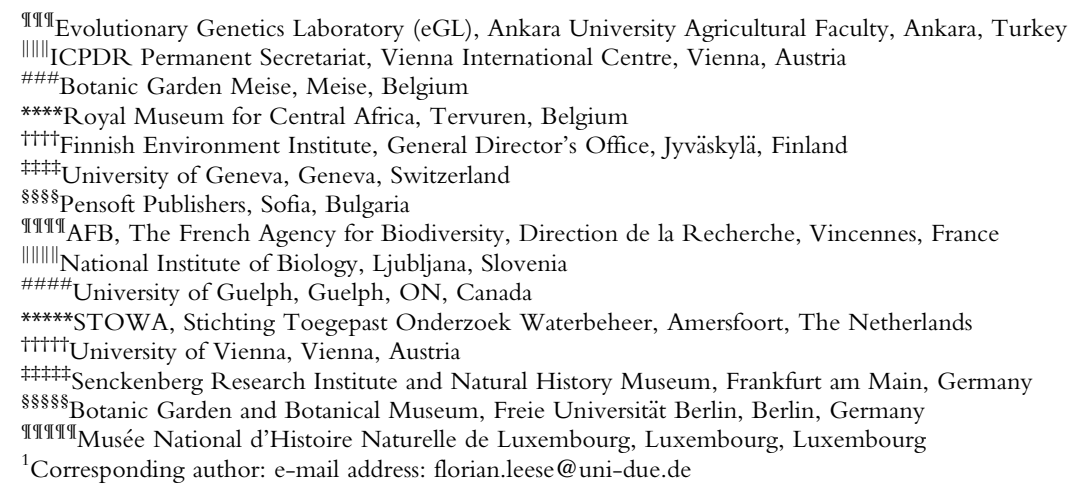

\section{Contents}

1. State and Fate of Aquatic Ecosystems

2. Advancement of Aquatic Biomonitoring With a Focus on Europe 5

3. A DNA-Based Next Generation of Aquatic Biomonitoring? 10

3.1 Revolutions in Sequencing Technology Drive Academic Progress 10

3.2 Metabarcoding and Other Genetic Approaches for Bioassessment 10

4. The Grand Challenges for Next-Generation Aquatic Biomonitoring 13

4.1 Genetic Data Cannot Deliver All Information Required by Legislation 14

$\begin{array}{ll}4.2 \text { Adjusting the Reference Conditions } & 15\end{array}$

4.3 Stressor-Biodiversity Relationships 21

4.4 Technological Progress Hampers Continuity and Demands Standardisation $\quad 21$

4.5 Costs and Accessibility: A Janus-Headed Debate? 23

4.6 The Importance of Transdisciplinary Dialogue 24

5. The Aim of DNAqua-Net 25

5.1 Networks Among Countries, Across Generations and Disciplines 27

6. Next-Generation Biomonitoring Opens New Doors 28

Acknowledgements $\quad 30$

$\begin{array}{ll}\text { References } & 30\end{array}$

\section{Abstract}

Aquatic biomonitoring has become an essential task in Europe and many other regions as a consequence of strong anthropogenic pressures affecting the health of lakes, rivers, oceans and groundwater. A typical assessment of the environmental quality status, such as it is required by European but also North American and other legislation, relies on matching the composition of assemblages of organisms identified using morphological criteria present in aquatic ecosystems to those expected in the absence of anthropogenic pressures. Through decade-long and difficult intercalibration exercises among networks of regulators and scientists in European countries, a pragmatic biomonitoring approach was developed and adopted, which now produces invaluable information. Nonetheless, this approach is based on several hundred different protocols, making 
it susceptible to issues with comparability, scale and resolution. Furthermore, data acquisition is often slow due to a lack of taxonomic experts for many taxa and regions and time-consuming morphological identification of organisms. High-throughput genetic screening methods such as (e)DNA metabarcoding have been proposed as a possible solution to these shortcomings. Such "next-generation biomonitoring", also termed "biomonitoring 2.0", has many advantages over the traditional approach in terms of speed, comparability and costs. It also creates the potential to include new bioindicators and thereby further improves the assessment of aquatic ecosystem health. However, several major conceptual and technological challenges still hinder its implementation into legal and regulatory frameworks. Academic scientists sometimes tend to overlook legal or socioeconomic constraints, which regulators have to consider on a regular basis. Moreover, quantification of species abundance or biomass remains a significant bottleneck to releasing the full potential of these approaches. Here, we highlight the main challenges for next-generation aquatic biomonitoring and outline principles and good practices to address these with an emphasis on bridging traditional disciplinary boundaries between academics, regulators, stakeholders and industry.

\section{STATE AND FATE OF AQUATIC ECOSYSTEMS}

The decline of biodiversity and ecosystem functioning in aquatic systems has direct effects on human well-being through alteration of ecosystem services (Millennium Ecosystem Assessment, 2005; Mulder et al., 2015; Vörösmarty et al., 2010; WWF, 2016). It is caused by many human activities, in particular pollution, habitat degradation, flow modification, overexploitation and the spread of invasive species as well as the direct and indirect effects of climate change (Dudgeon et al., 2006). To counteract the degradation of aquatic ecosystems, various pieces of legislation and associated mitigation and restoration strategies have been put into place, ranging from global initiatives such as the Convention on Biological Diversity (CBD, 1992), through European Union directives such as the Water Framework Directive (WFD, Directive 2000/60/EC), the Marine Strategy Framework Directive (MSFD, Directive 2008/56/EC), the Groundwater Directive (GWD, Directive 2006/118/EC) or the Habitats Directive (Directive 92/43/EEC), to a multitude of national, regional (including transboundary) and local programmes. All these require data on the condition of aquatic ecosystems. In most cases, these data are not restricted to environmental variables but also include biological data to measure ecosystem integrity and health for rivers, lakes, wetlands, estuaries and oceans (Birk et al., 2012; Borja et al., 2010, 2016; Hawkins et al., 2000). In a legal context, such assessments are expected to be performed in a recurrent and standardised fashion 
across those states that ratified the legislation, so that baselines can be established and responses to environmental change are consistent among participants. The biomonitoring programmes for aquatic ecosystems range from simple recording of presence (or abundance) of individual species to sophisticated multilayer programmes involving multiple organismal groups, often representing the result of many years of intense dialogue and regular adjustments. But now, novel genetic tools are emerging, which could revolutionise how we assess and document our environment and communicate the results (Bohmann et al., 2014; Bourlat et al., 2013; Deiner et al., 2016; Hajibabaei et al., 2011; Kermarrec et al., 2013; Taberlet et al., 2012; Valentini et al., 2016; Vasselon et al., 2017a; Woodward et al., 2013). Sometimes termed "biomonitoring 2.0" (Baird and Hajibabaei, 2012; Woodward et al., 2013) or "next-generation monitoring” (Bohan et al., 2017; Valentini et al., 2016), these approaches are increasingly applied in academic studies (Fig. 1). However, outside academia, they have yet to play a significant role in local to large-scale formal bioassessment programmes. The only exception are a few initiatives working on the detection of single rare/endangered or

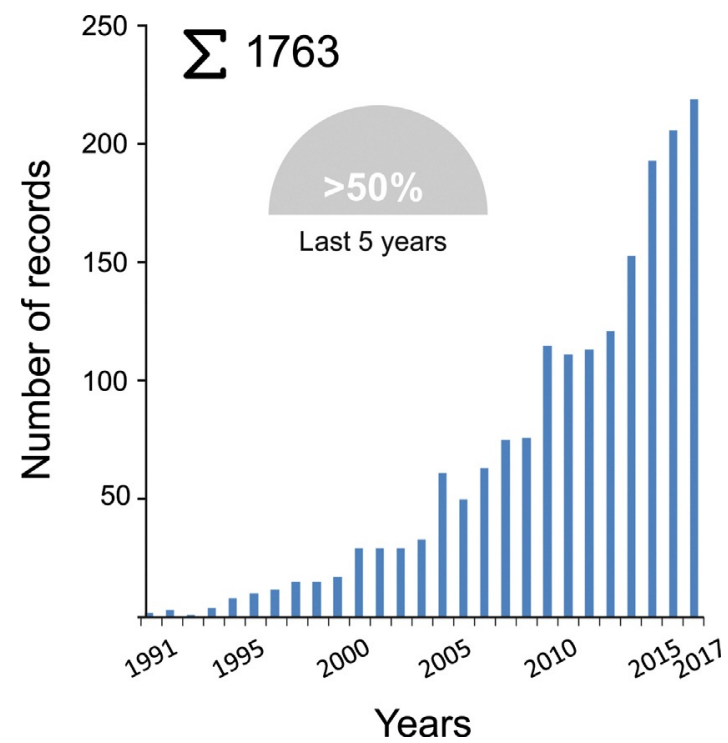

Fig. 1 Growing number of almost exclusively academic genetic biomonitoring studies as revealed by a web of science analysis. The search string "( $"$ "*monitoring" OR "*assessment") AND ("*water" OR "marine" OR "aquatic" OR "lake" OR "stream" OR "ocean" OR "river" OR "catchment") AND ("molecular" OR "genetic" OR "DNA") AND ("identif*" OR "characteri*" OR "*barcod*") AND ("PCR" OR "NGS" OR "HTS" OR "sequenc*"))" was applied on 02.01.2018. http://dnaqua.net. 
invasive alien species, such as the Great Crested Newt in the United Kingdom (Biggs et al., 2015), the Asian carp species in the Great Lakes (Jerde et al., 2013) and programmes aimed at detecting invasive species in Switzerland (Mächler et al., 2014). The higher organisational levels of communities, food webs and ecosystems have been largely ignored.

We argue that the current situation is not only the result of technical constraints but also largely due to the consequence of a substantial information gap between academic and regulatory communities, in part driven by the fear of difficult, complex and costly adaptations of well-established monitoring programmes (Friberg et al., 2011). The tremendous progress made in the past few years has largely gone unnoticed among a large user group due to a communication gap between disjunct communities and as a consequence of deeply rooted national traditions (Kelly et al., 2015). In fact, rigorous DNAbased biomonitoring studies dealing with real monitoring data and questions of intercalibration are still lacking: sustainable interdisciplinary networks are clearly needed to identify and establish state-of-the-art biomonitoring strategies, and to cover understudied yet important ecosystems such as groundwater.

In this review, we (i) provide a brief introduction to the history of aquatic biomonitoring programmes, (ii) highlight the main impacts of novel genetic methods on aquatic ecosystem assessments, (iii) describe the key technological and conceptual challenges preventing their use in biomonitoring programmes to date and (iv) introduce the recently established DNAquaNet COST Action (European Cooperation in Science and Technology), which aims to bridge the gap between science and application in using DNA-based methods in biomonitoring.

\section{ADVANCEMENT OF AQUATIC BIOMONITORING WITH A FOCUS ON EUROPE}

Aquatic biomonitoring can be dated back to at least the mid-19th century. Between 1870 and 1930, marine and lake biological stations proliferated across Western Europe and North America (Bont, 2015; Egerton, 2014), forming an important, yet largely academic network to study marine and freshwater biodiversity over time. However, these networks were typically restricted to one or a few ecosystems per country (Bont, 2015). Furthermore, the approach to assess and study ecosystems varied greatly due to the lack of regular interaction among researchers and practitioners in the predigital information age. Aquatic biomonitoring in its strict sense of 
identifying changes in response to human pressures over time only started in earnest in the early 20th century, when we learned that organic pollution of water bodies negatively impacted inland water ecosystems and thereby affected human well-being (Butcher, 1946). One of the first bioassessment protocols to be applied was the Saprobic System for running waters, an approach that dates back to the mid-19th century (widely Cohn, 1853), although its use for rivers started in the early 20th century (Kolkwitz and Marsson, 1902, 1908, 1909). More sophisticated measures to quantify the condition of aquatic ecosystems were developed over the following decades specifically to assess the degree of organic pollution by using benthic invertebrates, as well as introducing bacteria, ciliates and diatoms as new indicator groups (Sládeček, 1965). Unfortunately, and partly due to difficulties in peer-network communication, many of these methods remained country-specific and there were few examples of larger scale integration.

During the late 1960s, pollution in the United States became such a problem that the Clean Water Act (CWA; United States, 1972), a milestone of environmental legislation, was passed in 1972. The CWA requires each US state to reach clearly defined water quality standards with respect to chemical, physical and biological factors. Although there was a federal law to control aquatic pollution, the CWA of 1972 can be regarded as a starting point for worldwide national and international environmental legislation.

Marine monitoring in a stricter sense started later than in freshwater ecosystems, i.e. during the 1970s, when environmental degradation in marine ecosystems became more apparent in a number of developed countries. Around that time, the theoretical basis of the response of marine communities to human disturbance started to be better understood (Pearson and Rosenberg, 1978): in the 1980s and 1990s, researchers used biomonitoring data to develop well-defined numerical methods with the goal to detect and reflect stress in those communities (Gray and Elliott, 2009). Their work resulted in methods and indicators that went beyond the application of classical saproby-based indices (see Karr, 1991 for freshwater ecosystems) and included primary (i.e. abundance, richness and biomass) and derived structural variables (i.e. diversity indices, abundance and biomass ratios and evenness indices) (e.g. Diaz et al., 2004; Gray and Elliott, 2009). This also included a conceptual shift from "bioindication," i.e., measuring the magnitude of pollution using specific indicator taxa-to a more systemic approach assessing ecosystem integrity. 
In Europe, the WFD and some of its more local precursors built on these ideas as it pushed for the development of standardised protocols and the use of multiple organismal groups to assess the ecological status of different biological elements. The WFD encouraged regulators to move away from measuring and assessing the magnitude of individual stressors and looked towards developing more integrated assessments of aquatic ecosystems by identifying the disparity between the observed and the expected status of a water body. At the core of the WFD-compliant assessment methods lies the definition of type-specific reference condition, against which the observed community is compared. This can be done either by comparing the values of biotic metrics or alternatively through prediction systems (Moss et al., 1987). Furthermore, the WFD stipulates which organism groups are to be monitored for the individual aquatic ecosystem types: i.e. phytoplankton, attached plants and algae, benthic invertebrates and fish. At the end of the 1990s, and especially after 2000, a plethora of methods, also metaphorically described as an "adaptive radiation of assessment methods" (Kelly et al., 2015), were published and implemented, often piecemeal, in European countries. Today, these add up to more than 300 national methods for the WFD alone (Birk et al., 2012). In reality, however, a larger subset of those are adaptations of more generally applicable methods, which individual European countries favoured rather than standardised Europe-wide methods, accounting for particular taxa, stress combinations and river or lake types abundant and relevant to their respective countries. Still, differences between countries with similar water bodies may be regarded to some extent as a reflection of the specific national traditions, rather than the sole result of scientific evidence per se (Kelly et al., 2015). In essence, all these methods have similar targets: (i) to quantify the environmental state and difference from reference conditions, and (ii) to identify the causes of degradation as important background information from which appropriate management measures can be derived.

While the methods differ between aquatic ecosystem types, countries and organismal groups ("biological quality elements", BQEs), there are broad similarities in the general steps of the assessment workflow and all approaches rely on traditional morphological taxonomy. The typical six steps of bioassessment programs are shown in Fig. 2. Step 1: Samples are obtained from aquatic ecosystems using taxon-specific gear and methods (e.g. kick-nets, plankton-samplers, electrofishing). Step 2: These samples are processed in the field or lab and in Step 3 identified to the required 


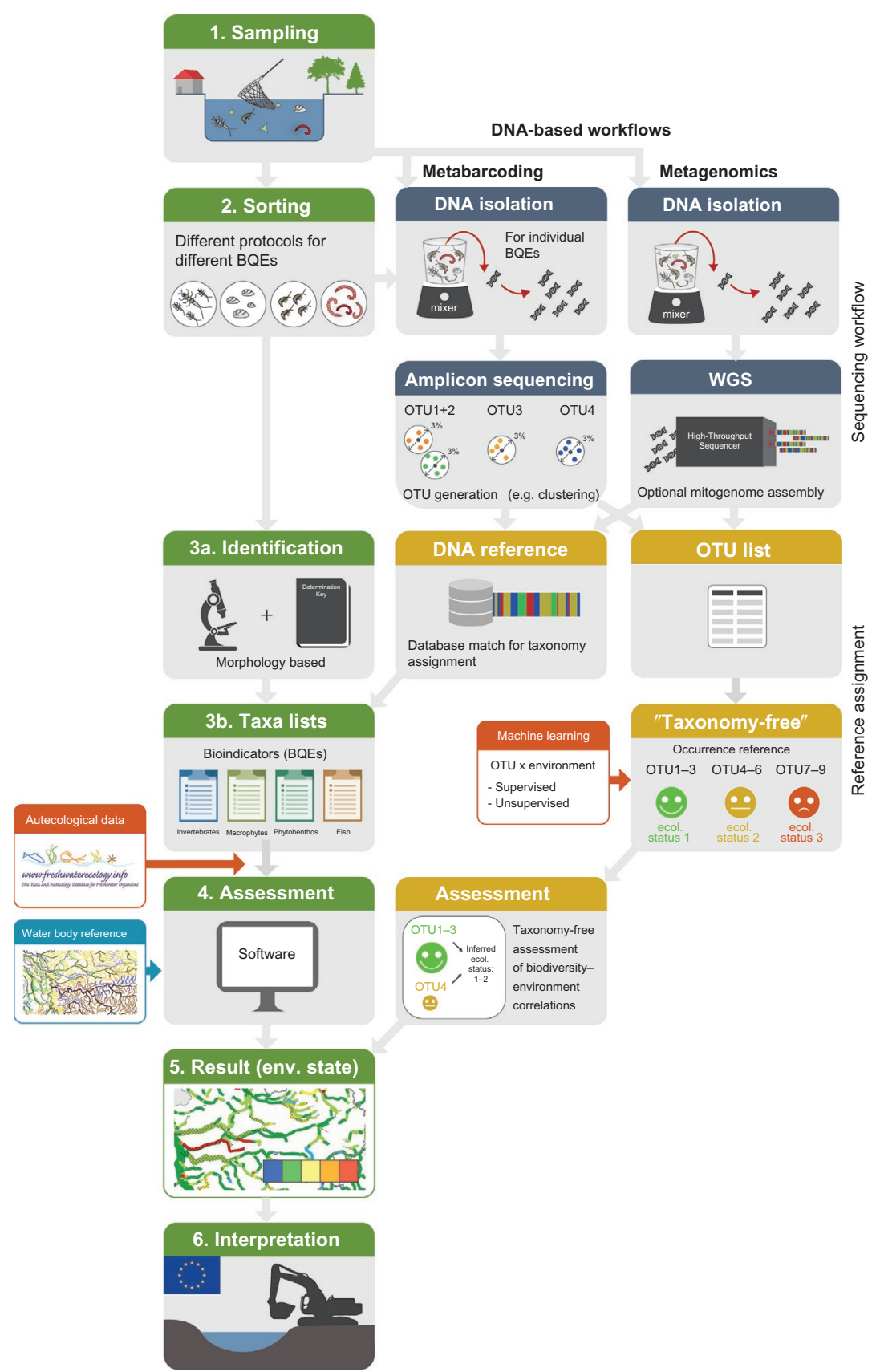

Fig. 2 Overview of the typical workflow used in aquatic bioassessment (Steps 1-6, left; boxes with green headers): (1) samples are collected in the field, usually independently for each "biological quality element" (BQE), (2) sorted or subsampled in the lab, (3) 
or possible taxonomic level, which can be species (usually for fish, diatoms, macrophytes and some cases for macroinvertebrates) or genus to family level. The generated taxa lists are used in Step 4 for bioassessment, typically calculating biotic indices. Here, the taxa lists are linked to information on their ecological preferences using either taxonomic or functional (i.e. bioecological traits) information (e.g. Schmidt-Kloiber and Hering, 2015) to calculate metrics. Those can either be used individually or in combination (e.g. into multimetric indices), or via prediction systems that just compare taxa lists to reference conditions without calculating indices (Apothéloz-Perret-Gentil et al., 2017; Cordier et al., 2017). The results are used in Step 5 to identify the ecological/environmental status (Borja et al., 2012) by calculating the statistical distance of the observed values from values expected in reference conditions (i.e. the "high" status). While Steps 1-4 vary among countries, intercalibration procedures guaranteed the comparability of the ecological status classes used in different countries. Finally, in Step 6, the assessment results are used to inform management decisions, in particular for water bodies not meeting the desired "good ecological status".

With respect to the classical workflow shown (Fig. 2), we argue that next-generation aquatic biomonitoring based on genetic data could substantially improve several of the six steps in bioassessment and contribute to a better management of aquatic ecosystems.

identified using morphological traits of the BQEs to produce taxa lists. (4) The actual assessment is performed using the taxa lists obtained and by comparing them to expected communities for the water body type studied (horizontal lines), according to "reference" conditions. (5) The assessment leads to an assignment of an ecological quality class. (6) Assessment results are interpreted. In case of a greater than permitted mismatch with reference conditions (e.g. less than "good" ecological quality status for the WFD) appropriate measures have to be taken in order to improve ecological status. Genetic data can be used in the process in different ways using either amplicon (metabarcoding, middle column) or whole-genome shotgun sequencing (WGS) metagenomics data (right column). The data produced by both DNA-based approaches can be used to query obtained Operational Taxonomic Units (OTUs) against reference databases in order to produce taxa lists and continue with the traditional assessment (without abundance data). However, it is also possible to avoid the assignment of OTUs to Linnaean taxonomy but assign OTUs independent of their classification to environmental conditions either using training data (supervised machine learning) or through environmental correlations (unsupervised machine learning). Through this approach, a much broader set of biota can be used to derive novel indices for environmental assessment. $h$ ttp://dnaqua.net. 


\section{A DNA-BASED NEXT GENERATION OF AQUATIC BIOMONITORING?}

\subsection{Revolutions in Sequencing Technology Drive Academic Progress}

Today, we are witnessing a revolution in the field of genomics. The introduction of new high-throughput sequencing (HTS) platforms allows for the analysis and identification not only of individual specimens but also of whole communities. High-throughput amplicon sequencing, commonly termed DNA metabarcoding (Taberlet et al., 2012), is an example of how technology initially developed for applications in the fields of medicine, forensics and microbiology is now being adapted to advance environmental monitoring (Staats et al., 2016). Today's HTS machines such as Illumina's NovaSeq are capable of producing billions of sequences in a single run, making it possible to analyse hundreds of samples in parallel and to identify hundreds of species per sample each. However, such an explosion challenges current analytical protocols due to the increase of computation load, and suggests that a move towards high performance computing (HPC) could be relevant. The number of academic studies that utilise high-throughput genetic bioassessment is increasing at an accelerating rate (Fig. 1). Perhaps unsurprisingly, given the different logistical challenges involved in biomonitoring, the first attempt to extend this academic work into applied biomonitoring happened in Canada: The Canadian Aquatic Biomonitoring Network (CABIN) has to monitor a huge number and a vast area of water bodies covering over 9 million $\mathrm{km}^{2}$, with considerably fewer human resources and more limited taxonomic baseline data than is the case for most European countries. Consequently, in order to ensure sustainable monitoring of Canada's aquatic ecosystems, several different approaches using genetic data have been suggested and are now in regular use (Baird and Hajibabaei, 2012; Gibson et al., 2015; Hajibabaei et al., 2011; Hajibabaei et al., 2016) to improve speed, resolution, costs and comparability in cooperation between CABIN and WWF (World Wildlife Fund).

\subsection{Metabarcoding and Other Genetic Approaches for Bioassessment}

The methods proposed represent an extension to the classical DNA barcoding approach (Hebert et al., 2003), moving from identifying single specimens, where the question is "what species is this?", to describing community composition of mixed taxon samples, where the question is "what 
species are there?". These mixed samples can take various forms including bulk invertebrate or biofilm samples ("biodiversity soup" sensu Yu et al., 2012) and mixed-species DNA extracted from water or sediment (=environmental or "eDNA"). In short, eDNA or DNA of bulk samples is extracted and subjected to one of a number of different molecular approaches (see Fig. 3). DNA metabarcoding (Taberlet et al., 2012) probably represents the most widely tested and validated approach to date for processing mixed taxon samples. Over the last decade, metabarcoding and metagenomic studies have led to an enormous increase in the amount of available genetic data for organisms, communities and habitats (e.g. Bik et al., 2012; de Vargas et al., 2015; Elbrecht and Leese, 2017; Radom
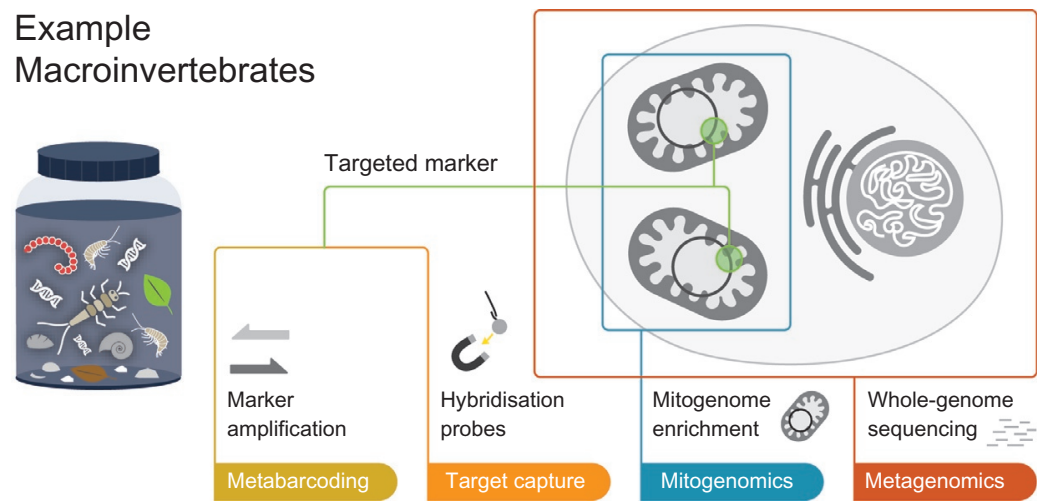

\begin{tabular}{|c|c|c|c|c|}
\hline Taxonomic resolution & Good & Good & Very good & Very good \\
\hline Needed sequ. depth & Medium & Low & Low & Very high ${ }^{a}$ \\
\hline Primer bias & Yes & Maybe & No & No \\
\hline$\rightarrow$ Taxa missed & $\sim 20 \%$ & $20 \% ?$ & $0 \%$ & $0 \%$ \\
\hline \ Biomass/abundance & p/a only & Maybe & Maybe & Maybe \\
\hline Reference data & Good & Good & Medium $^{b, c}$ & Poor $^{b}$ \\
\hline Method validation & Good & Poor & Poor & Good \\
\hline Constraints & & \multicolumn{3}{|c|}{ Fresh tissue needed } \\
\hline
\end{tabular}

Fig. 3 The potential of different DNA-based approaches is currently being assessed for application in biomonitoring programmes, as shown here for benthic macroinvertebrates. All methods have different advantages and biases. To date, metabarcoding is a well validated method and has good reference databases. This makes this approach advantageous for next-generation biomonitoring in the near future, whereas the other approaches need further validation or other improvements but could be even more promising in the long run. http://dnaqua.net, modified after Elbrecht, V., April 2017. Development of DNA metabarcoding methods for stream ecosystem assessment. PhD Thesis, University of Duisburg-Essen. 
et al., 2012; Thomsen et al., 2012; Vasselon et al., 2017a) with most studies comparing the performance of morphological and metabarcoding methods for monitoring purposes (Couto et al., 2016; Elbrecht et al., 2017b; Kermarrec et al., 2013; Lejzerowicz et al., 2015; Stoeckle et al., 2017; Vasselon et al., 2017a; Vivien et al., 2015; Zimmermann et al., 2015). Available data suggest that in principle morphological- and metabarcoding-based assessment systems are compatible and can even use the very same sampling protocols. Community metabarcoding relies on PCR amplification using "universal", i.e., nonspecific primers and thus induces amplification bias when the primers inevitably match some taxa better than others (Elbrecht and Leese, 2015; Krehenwinkel et al., 2017). The use of hybridisation probes could potentially counteract this bias by allowing the targeted capture of barcoding genes (Dowle et al., 2016; Shokralla et al., 2016), although biases may still be introduced in hybridisation when too few probes for certain taxa are available in the experimental setup (i.e. being saturated) or are not a good match to the targeted taxa.

An alternative method to using specific probes or primers is to sequence the extracted bulk DNA directly, without PCR (Zhou et al., 2013). These metagenomics or mitochondrial metagenomics techniques (see, e.g., Crampton-Platt et al., 2016) omit the majority of problems associated with PCR-based metabarcoding, i.e., the ability to perform direct quantitative measures for certain taxa by hampering the relationship of sequence reads and taxon biomass/abundance, and even the loss of some taxonomic groups due to incompatible primer binding sites (Pinol et al., 2015). Such a metagenomic sequencing technique is well established for bacterial communities (Tseng and Tang, 2014) and was recently applied to arthropods (e.g. Arribas et al., 2016; Cicconardi et al., 2017). Enrichment of mitochondria is also possible, reducing sequencing depth and thus lowering the costs per sample (Macher et al., 2017). However, mitogenomes represent only a fraction of the total DNA and metagenomic sequencing generally requires substantially deeper sequencing than PCR-based approaches. Furthermore, for selected genes such as COI that is widely used in sequencing studies of animals, good reference databases are available, which is not yet true for complete mitogenomes of aquatic organisms. At this point, the use of metabarcoding with carefully designed and ecosystem-specific target-gene primer sets is advisable: in vitro and in silico tests should be performed to validate the applicability of the primer pair in the desired ecosystem (e.g. marine coastal habitat, high alpine lake, lowland streams, etc.) and taxonomic context (different ecosystems typically host different taxa) and to allow robust 
interpretations of genetic biomonitoring results. The newer PCR-free techniques have huge potential, but have not been sufficiently validated yet and lack proper reference data for deployment in routine monitoring schemes. Once established, they could, however, be employed in the future to reanalyse and "hindcast" archived DNA samples and provide additional options for the analysis of DNA-based biomonitoring.

Another, more radical alternative to the taxonomy-based (metabarcoding or metagenomics) approach could be the so-called taxonomy-free approach (Apothéloz-Perret-Gentil et al., 2017; Cordier et al., 2017), founding ecological assessments directly on genetic data as a proxy for communities without a Linnaean assignment step (or taxonomy assigned only to higher taxonomic levels such as phyla, orders or families) but simply using machine learning algorithms to link presence of genetic entities with environmental factors (see Fig. 2). Furthermore, extracting information on individual sequence variants (i.e. all nonidentical DNA sequences, omitting the OTU clustering step) from bulk metabarcoding datasets holds great potential for monitoring (Callahan et al., 2017). With this approach, also changes in intraspecific genetic diversity can be monitored (Amir et al., 2017; Callahan et al., 2016; Eren et al., 2013). While these methods have successfully been applied to identify sequence variants in microbial metabarcoding datasets, applying them to macroinvertebrate bulk samples is more challenging because specimen biomasses often vary by several orders of magnitudes and sequence variants of small specimens might go undetected because they are overshadowed by sequences of biomass-rich specimens, especially if sequencing depths is too shallow (but see Elbrecht et al., 2017a).

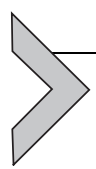

\section{THE GRAND CHALLENGES FOR NEXT-GENERATION AQUATIC BIOMONITORING}

Current sample processing and taxonomic identification could be shifted towards the use of modern HTS approaches, in particular DNA metabarcoding. The traditional workflow could remain largely unchanged, with DNA-based tools simply replacing morphological work, which is still rooted in labour-intensive light microscopy (see Fig. 2). Initial tests show similar results for both marine and freshwater biomonitoring (Aylagas et al., 2014; Elbrecht et al., 2017b; Lejzerowicz et al., 2015), suggesting that a rather straightforward implementation into the classical workflow may be achievable. However, a shift from traditional morphology-based assessments to DNA-based methods may be 


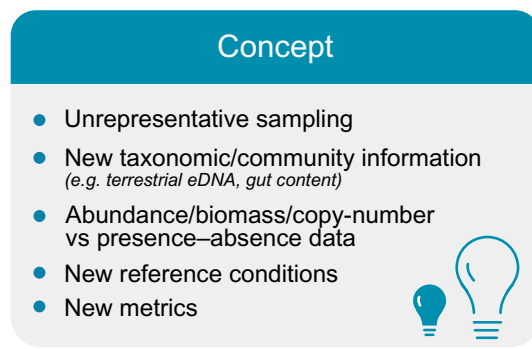

Perception

- New "units" to quantify biodiversity

- New technical language

More complex/integrative settings

\section{Technology}

- Sample/storage conditions (e.g. preservation liquid, inhibitors)

- Primer bias/PCR stochasticity

- Misidentifications

(e.g. wrong references, shared barcodes)

- Reference database development

- Noncorresponding taxonomy (e.g. between reference list and results)

\section{Economic and legal framework}

- Costs

- Knowledge transfer

- Legislative requirements (e.g. abundance data, intercalibration)

Fig. 4 The main challenges hindering the straightforward application of DNA-based tools in aquatic biomonitoring. See text for further explanation. http://dnaqua.net.

complicated by a range of issues related to technology, concept, perception as well as economic and legal frameworks (see Fig. 4). These are discussed in more detail below.

\subsection{Genetic Data Cannot Deliver All Information Required by Legislation}

The WFD and MSFD explicitly state that in bioassessments "composition and abundance" (Annex V and III, respectively) of BQEs need to be accounted for. Until now, issues such as unequal biomass of multicellular organisms and in particular primer bias greatly hamper the (current) ability of metabarcoding to deliver abundance data for a wide range of indicator taxa. Although several studies have shown that this bias can be reduced with optimised and in silico evaluated primer combinations (Elbrecht and Leese, 2017) and that correction factors can be calculated under certain assumptions (e.g. Krehenwinkel et al., 2017; Thomas et al., 2016), it is clear that metabarcoding cannot deliver absolute abundance data for complex communities of multicellular organisms (Elbrecht et al., 2017b). If primer bias can be reduced or eliminated, e.g., through the use of PCR-free HTS approaches, it may be possible to use mito-read number as a proxy for biomass (Choo et al., 2017). This would be a major breakthrough for 
bioassessment options but also for novel ecological assessments, as more direct links to food web structure, ecosystem processes and ecosystem services. However, varying biomass within species and varying mitochondrial copy number among cells, developmental stages, organisms and taxa mean that the link with abundance will remain weak, particularly for samples that contain a diverse assemblage of taxa or eDNA. In addition to hampering inference of abundance measures, primer bias can cause important taxa to be missed, particularly where a single set of primers is relied upon for analysis of diverse assemblages. Subsampling options or site-occupancy approaches might be options to quantify abundance. However, in terms of the current bioassessment workflow, it is interesting to note that even after the omission of a number of taxa due to their lack in reference databases, ecological status assessments can be robust (Vasselon et al., 2017b), even if only presenceabsence data are used (Aylagas et al., 2014; Elbrecht et al., 2017a,b).

\subsection{Adjusting the Reference Conditions}

The "good ecological status" of the WFD and the "good environmental status" of the MSFD require comparisons with undisturbed, and in the context of the WFD, type-specific, reference conditions (Borja et al., 2012; Hering et al., 2006). A substantial amount of work in the past two decades has been invested into defining supposed reference conditions for a multitude of water body types (when possible), and exploring how biotic communities in degraded water bodies deviate from them. Current reference conditions of water bodies (both reference taxa lists and reference metric values) have been based on morphological identification methods and are only considered valid if these methods are applied. Recent data indicate that outcomes from DNA-based studies seem to be very compatible with morphology-based assessments, but a shift to DNA-based tools comes with both gains and losses. Metabarcoding typically retrieves taxa overlooked by morphological analyses, particularly cryptic species, endoparasites, ingested organisms or species that are represented by small, unidentifiable juvenile states or sexes. In some cases, the number of taxa is quite high compared to that found in morphological analysis, even when including biological replicates and strict error filtering (e.g. Elbrecht et al., 2017b). Furthermore, genetic analyses can miss several potentially important indicator taxa such as nematodes that fail to amplify for the commonly used primers in the PCR step (see below) and also simply due to the currently incomplete reference databases. Consequently, it will be important that any future 
inclusion of genetic tools is accompanied by the addition of DNA-based descriptions of biotic communities at reference sites, and that the regular update of reference conditions takes this aspect into account. Otherwise, the finding of many more taxa with DNA-based approaches might bias richness-based indices and report a water body as being systematically (but inaccurately) better than would be the case with a traditional assessment. This point requires careful assessment and planning and forms a central topic of DNAqua-Net working groups (WG2 and 5, Fig. 5; see also Leese et al., 2016).

Taxonomic information is an integral part of all current bioassessment protocols. For pragmatic reasons (time/money constraints as well as identification problems) many focus on higher level taxonomy (typically genus or family) because all or most of the members of the respective taxa are considered to indicate similar ecological conditions, following the phylogenetic niche conservatism concept (e.g. Keck et al., 2016). According to this concept, closely related species are assumed to possess similar ecological characteristics and thus should indicate similar environmental conditions. However, species within genera can differ markedly in their ecological preferences and thus species-level resolution data sometimes provide more precise ecological information, which should, in theory, improve ecosystem health assessments (Macher et al., 2016; Schmidt-Kloiber and Nijboer, 2004). In principle, this may be especially relevant for assessments of biota having (partly) arised from sympatric speciation processes where different ecologies (ecological character displacement) rather than distinct distributions promoted diversification, e.g. plankton communities. Most frequently, specimens are identified using morphological criteria, and the Linnaean binomial nomenclature is used to query a database or software to retrieve taxon-specific ecological information. Genetic markers could provide similar or higher than species-level identification and thereby act as a link to reference databases of OTUs in the same manner. Overviews of markers and databases used are given in, e.g., Pawlowski et al. (2012) and Creer et al. (2016). The application of DNA barcoding has been hampered by a lack of reliable and comprehensive reference databases. This has been solved for several taxonomic groups and regions through national and international barcoding campaigns (see above). However, even now, there is no European or even global DNA barcode reference library for aquatic BQEs. A first overview of aquatic BQEs for selected regions was prepared by members of Working Group 1 of DNAqua-Net (Table 1; see Section 5). While reference libraries are fairly comprehensive for freshwater and marine fishes 


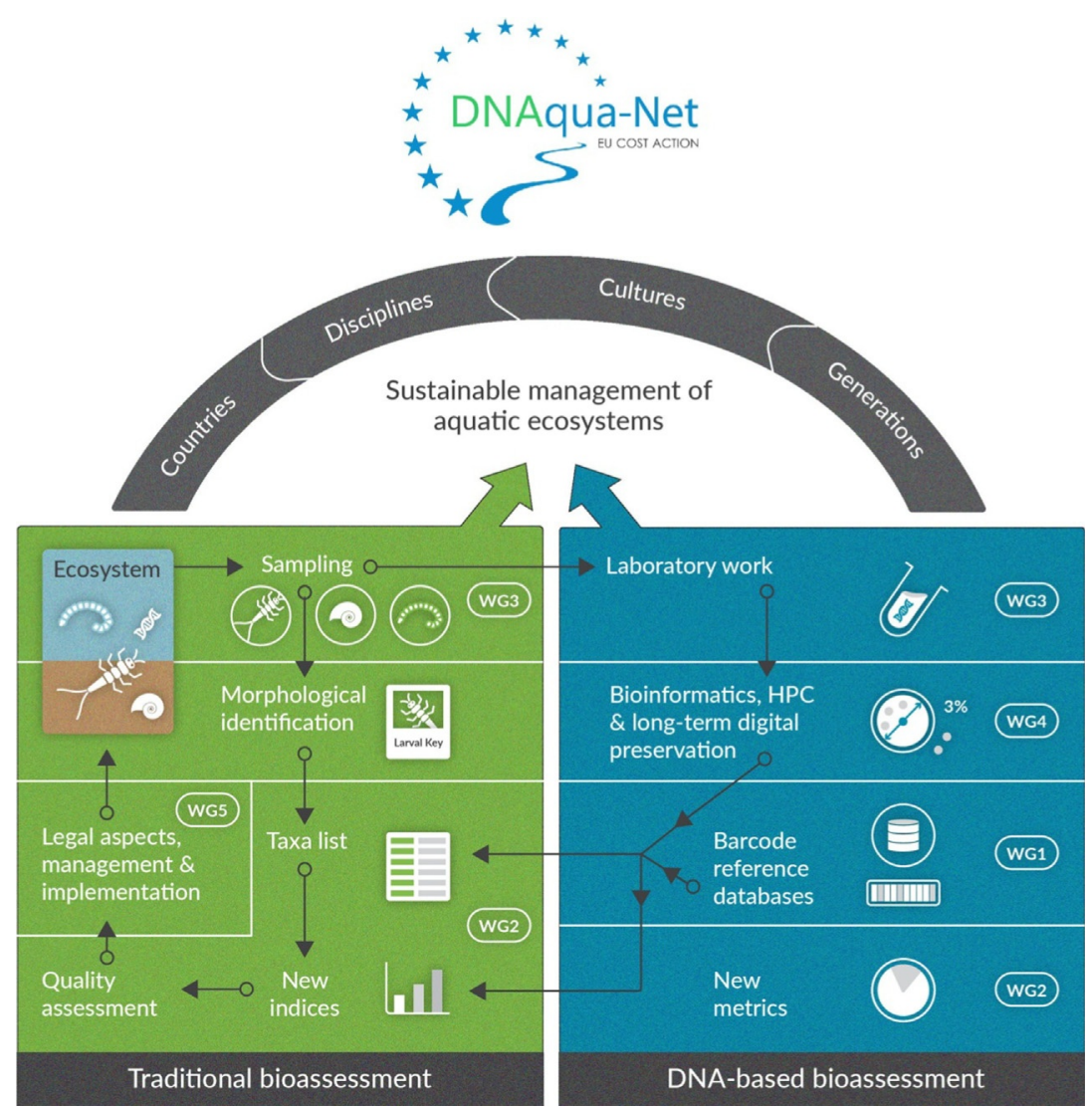

Fig. 5 Traditional biomonitoring in practice (left; green) and ways to include DNA-based methods (right; blue) into a "next-generation" programme for sustainable waterresource management. The roles of DNAqua-Net's five Working Groups (WG1-5) are indicated. WG1: DNA barcode references; WG2: biotic indices and metrics; WG3: field and lab protocols; WG4: data analysis and storage (HPC = high-performance computing); WG5: implementation strategy and legal issues. Further, the international and intersectoral DNAqua-Net consortium aims at developing novel genetic tools for bioassessment of aquatic ecosystems in Europe and beyond, thereby bridging countries, disciplines, cultures (see Kelly et al., 2015) and generations. http://dnaqua.net.

as well as freshwater benthic macroinvertebrates, for major groups of European marine benthic macroinvertebrates, considerable compilation effort is still needed, as even in major groups such as Annelida, Crustacea and Mollusca (MZB) below 50\% of the taxa relevant for routine monitoring possess reference barcodes (Table 1). Reviewing available DNA barcode data revealed that even in groups with relatively good species coverage, we still 
Table 1 Overview of COI DNA Barcode Data Available (Bold) and Missing (Italics) for Formally Used Aquatic Animal Biological Quality Elements (BQEs) for Selected Countries/Regions

Macrozoobenthos (MZB)

Fish

\begin{tabular}{lllll}
\cline { 2 - 4 } Country & Freshwater & Marine & Freshwater & Marine \\
\hline Germany & $\mathbf{6 1 1} / 79(89 \%)$ & $\begin{array}{l}\mathbf{7 2} / 0 \\
(100 \%)\end{array}$ & \\
\hline Danube (JDS) & $\mathbf{2 8 0 / 7 2}(80 \%)$ & $\mathbf{6 2 / 4}(94 \%)$ & \\
\hline Luxembourg $^{\mathrm{a}}$ & Genera: $\mathbf{9 5 / 6 1}(61 \%)$ & $\mathbf{3 5} / 0$ \\
& Families: $\mathbf{1 0 3 / 1 9}(84 \%)$ & $(100 \%)$ & \\
\hline Norway & $\mathbf{2 2 9} / 21(92 \%)$ & $\mathbf{3 1 1} / 70(82 \%)$ & $\mathbf{3 7} / 0$ \\
& & & $(100 \%)$ & \\
\hline Europe & & $\mathbf{1 1 1 9 / 1 4 0 6}$ & $\mathbf{5 4 4 / 8 6}$ & $\mathbf{1 1 8 8} / 306$ \\
& & $(44 \%)^{\mathrm{b}}$ & $(86 \%)^{\mathrm{c}}$ & $(80 \%)^{\mathrm{d}}$ \\
\hline
\end{tabular}

Slovakia $\quad \mathbf{9 8 2 / 8 8 3 ( 5 3 \% )} \quad \mathbf{6 5} / 4(94 \%)$

${ }^{a}$ Reference list for MZB is based on family-, subfamily- and/or genus-level entries only. Coverage is given for family- and genus-level entries based on the checklist function implemented in BOLD (as on 02.01.2018).

${ }^{\mathrm{b}}$ Checklist generated from AMBI's species list, including all Annelida, Crustacea and Mollusca species reported for Europe (excluding Barents Sea and Black Sea). All available DNA barcodes, including unreviewed, unpublished data and specimens collected outside European marine regions.

${ }^{c}$ Based on all available DNA barcodes from the FREDIE consortium (www.fredie.eu) including yet unpublished data, including 21 extinct and 44 alien species.

${ }^{\mathrm{d}}$ Based on ERMS checklist, only Actinopterygii, Elasmobranchii and Holocephali. All available DNA barcodes, including unreviewed, unpublished data and specimens collected outside European marine regions.

Percent coverage in the Barcode of Life Data Systems (BOLD) in parenthesis.

lack baseline information on local genetic variability, i.e., barcodes typically come from a few campaigns conducted in a small subset of the range of a given species and do not cover its genetic diversity. For example, almost all fish species known to occur in Slovakia are represented by DNA barcodes; however, only $4 \%$ of them are derived from samples actually collected in Slovakia. The situation is similar for freshwater macroinvertebrates, with only $2 \%-3 \%$ of all referenced species possessing barcodes from Slovakian specimens. Bergsten et al. (2012) showed that geographical coverage of sampling is important in order to correctly apply DNA barcoding and, e.g., not split two geographically distinct population of the same species into two different species. This highlights the need to support local barcoding campaigns in order to ensure better coverage of species ranges but also to link faunistic/floristic databases such as the Fauna Europaea 
(https://fauna-eu.org) to DNA barcode databases, as otherwise the uncertainty of identification can increase with the growing data available (Bergsten et al., 2012).

For diatoms, the chloroplast marker rbcL is used for barcoding. However, the taxonomic coverage is still very sparse due to the complications associated with isolating and culturing species prior to barcoding (Rimet et al., 2016). For example, 1437 taxa are reported on the German red list (Lange-Bertalot and Steindorf, 1996). Of these, however, only 19.5\% are available in a barcode reference library (Zimmermann J., personal communication). For Slovakia, the freshwater diatoms reference list used for WFD implementation includes 853 taxa (species/subspecies). Out of them 156 $(18 \%)$ possess records in the Barcode of Life Data System (BOLD), but only four species $(<0.5 \%)$ have a barcode. For Sweden, 1317 taxa are on the official diatom taxa list, for which only $13 \%$ and $16 \%$ (rbcL and $18 \mathrm{~S}$ barcode marker, respectively) are represented by reference barcode data (M. Kahlert, personal communication). In France, for the 600 more common diatom species, only 140 (23.3\%) have an rbcL barcode (A. Bouchez, personal communication). However, the increasing quantity of HTS sequences obtained from environmental diatom samples may be efficiently used to fuel current databases (Rimet et al., 2018). Rimet et al. (2018) show that it is possible to link hitherto unidentified barcodes from HTS output to Linnaean binomials using phylogenetic tools with high certainty as long as certain criteria are met (e.g. low diversity diatom assemblages and relatively high frequency of target organism in both HTS output and corresponding light microscopical analysis).

While many national barcoding campaigns have contributed substantial amounts of sequence data, coverage remains spatially fragmented, taxonomically incomplete and disconnected from available autecological trait databases. Recent studies (Elbrecht et al., 2017b; Vasselon et al., 2017a) have documented high proportions of taxa that were identified using morphological traits but not found in the genetic analyses of the bulk samples (30\% for freshwater macroinvertebrates and $68 \%$ for diatoms). This can to some extent be attributed to a lack of available reference barcodes (especially for diatoms), as only those taxa that have a corresponding record in the database can be detected and assigned with genetic methods. Other factors that may contribute to these differences include misidentifications and primer bias. In order to improve both speed and robustness for DNA-based assessment, skilled taxonomists are needed to fill those gaps, since precision of assessment increases with the number of taxa assigned unequivocally 
(Haase et al., 2010; Rosser, 2017; Schmidt-Kloiber and Nijboer, 2004; Stein et al., 2014).

Another reason to embed expert taxonomists in the process of developing a next-generation biomonitoring concept is the fact that species names (or species hypotheses), especially among more cryptic taxa, are often dynamic entities under constant revision and therefore subject to change. Many species are still being lumped, split, synonymised or transferred between higher taxonomic levels and many monitoring lists use rather outdated taxonomy as they are not updated regularly. This is the case for WFD assessments using phytoplankton, for instance, where analysts often use identification keys written in the 1970s, which do not follow the current taxonomy of microalgae. Current literature on microalgae taxonomy now integrates DNA data and electron microscopy observations to delimit species boundaries. Such features are of little use in determinations based on light microscopy. Other organism groups have cryptic or nearly cryptic species that are difficult to distinguish using light microscopy (e.g. Jörger and Schrödl, 2013; Lin et al., 2017). Simple comparisons of taxa lists used by managers with DNA reference databases without questioning data validity can lead to gross underestimates of availability and coverage of available DNA barcode references, because the species names listed in the manager's lists might be outdated and not connected to the most current taxonomic classification used in the reference database, or vice versa. For instance, a gap analysis for fish species used for biomonitoring in Luxembourg utilising BOLD's checklist function revealed several taxa with no available DNA barcode reference data (Weigand A.M., unpublished data). However, after updating the taxonomy of the WFD-relevant taxa list and including a synonomy list in BOLD, the coverage increased from $86 \%$ to $100 \%$. The opposite is also possible: a straightforward comparison of the marine European fish species against the DNA barcode reference library entries revealed that $39 \%$ of species had ambiguous DNA barcode references associated. However, this amount decreased to only 13\% after critical revision of the records' incongruences (Oliveira et al., 2016). About $60 \%$ of the detected mismatches resulted from syntax errors, synonyms, mislabelling and contamination.

Another conceptual challenge with respect to barcode-based species assessment is that different barcodes do not necessarily represent different species and vice versa, identical barcodes may include more than one species (e.g. Bergsten et al., 2012). Hence, reference data revision and curation as well as the inference of biological trait data are much needed and, ideally, 
should result from the coordinated efforts of taxonomists, ecologists, geneticists and database managers (Ekrem et al., 2007). Linking and promoting taxonomic research through the network is one of the central goals of DNAqua-Net. Our strategy is to collaborate with the Consortium of European Taxonomic Facilities (CETAF, http://www.cetaf.org) together with the international Barcode of Life project (iBOL, http://www.ibol.org) and national barcoding campaigns.

\subsection{Stressor-Biodiversity Relationships}

Even once we have standardised our baseline reference data, we will need to understand how these deviate from the desired state under environmental stress. At present, we still do not fully understand many of the details in stressor-biodiversity responses, especially when considering biodiversity responses from the level of genes through to community-level and related functional aspects. Stressors often co-occur in natural systems in space and/or time and the response of biota to them is not necessarily simple or linear as they may interact in antagonistic, synergistic and additive ways, generating "ecological surprises" (Hering et al., 2015; Jackson et al., 2016a; Townsend et al., 2008). The next generation of biomonitoring programmes will not necessarily solve these problems, but they could make important steps towards that goal given their ability to generate a far more comprehensive range of OTUs or even individual genotypes and hence response variables that could act in more nuanced ways than is the case with the coarse traditional methods currently in use (Jackson et al., 2016b; Macher et al., 2016). The role of genetic data is key as they (i) can diminish taxonomic uncertainty, (ii) provide information on additional taxa (such as bacterial or protist communities) and ecosystems, not currently included into traditional monitoring programmes, and (iii) deliver information on ecosystem functions, which may be affected more directly by multiple stressors. In times of increasing human impacts on ecosystems and climate change, this task will require large-scale coordinated research projects over the coming decades.

\subsection{Technological Progress Hampers Continuity and Demands Standardisation}

In Section 3, we highlighted the currently explored methods for DNAbased biomonitoring and it became obvious that some are quite advanced (metabarcoding), whereas others are still at the developmental stage 
(hybridisation techniques, metagenomics). This makes it difficult at the moment to provide clear guidance to regulators on which method to use. The EU's WFD, as a major piece of legislation with direct relevance to DNAqua-Net, is due to have a revision of procedures in 2019. Thus, consultations on revisions and amendments as well as decisions on which steps to include in the next monitoring cycle need to happen soon. Therefore, the rather exploratory approaches using target capture and metagenomics seem to be an inappropriate strategy to propose at the moment, compared to the relatively robust species presence-absence estimates provided by DNA metabarcoding. However, what is now exploratory might soon become standard. Therefore, revisions need to accommodate the possibility of new and powerful tools becoming available, despite current limitations. It may thus be more important to consider and develop Quality Assurance/ Quality Control (QA/QC) measures as well as intercalibration with previous approaches for any new DNA-based method to be used in biomonitoring rather than recommending specific tools and protocols. This could include the use of standardised, artificially added DNA of well-defined (yet unknown to the analyst) "mock communities" (i.e. combination of species-specific DNA isolates in the laboratory to design artificial communities for test purpose). The DNA or even complete samples can be routinely processed alongside real samples as internal quality checks, as well as ring tests and proficiency tests as external checks on the performance of laboratories. As a first example of its use in this field, proficiency testing was introduced for eDNA detection of the Great Crested Newt in the United Kingdom in 2017. The choice of methods to implement and evaluate novel DNA-based approaches in biomonitoring is open to debate, and a mutual understanding of their capacities, benefits and pitfalls is important. An understanding of legal frameworks will be necessary to inform these decisions. Moreover, it is also important to consider trade-offs in practicality and cost-effectiveness of the available approaches that will allow DNA-based monitoring to be carried out routinely by nonacademics in a robust and replicable manner. For example, it may not be realistic to propose a method that requires samples to be immediately transported to the laboratory on ice as the majority of field ecologists will not have access to the necessary resources and facilities for this. The question of promoting a possibility of routine processing with QA/QC for data analysis (bioinformatic pipelines) should be addressed as well, taking care of accessibility, versioning and repeatability of the selected bioinformatic filtering. 


\subsection{Costs and Accessibility: A Janus-Headed Debate?}

At this point, European monitoring is in a difficult situation: traditional biomonitoring approaches are-after more than a decade of testing and negotiations - in place and thus regulators and water managers have little interest in changing these established protocols (Friberg et al., 2011). Implementation of the WFD is already very complex to conduct and stability is desired. Intercalibration procedures have been implemented with some success and so have quality standards for many countries outside the EU (Poikane et al., 2014). As the success of the traditional biomonitoring workflow (Fig. 2) does not rely on sophisticated technological devices but rather on trained personnel, the process chain works in all European countries independently of their technological or economic development. However, in some EU countries with extended monitoring networks, both policy makers and water managers see the possibility that new DNA-based approaches may save money, as they could reduce the costs of labourintensive species identifications substantially. This holds true in particular for countries in which labour costs are high compared to sequencing costs and where sequencing technologies and labs are readily available. Here it becomes important to offset labour costs by making theoretical and methodological knowledge available to all countries.

We also see a need for new funding streams for research on biomonitoring data acquisition using both traditional and novel methods in a period of "handshaking" between the new and old technologies. This would allow researchers and practitioners to explore how best to exploit genetic methods without sacrificing backward-compatibility, which is a major bottleneck from a regulatory perspective in the context of WFD and MSFD. However, stakeholders and regulators often view such studies as R\&D activities that should not be funded by their budget, making their full engagement with academic programmes challenging. While there are notable exceptions such as the funding of the German Barcode of Life II phase ("Bridging science and application gap", funded by the German Federal Ministry of Education and Research) and the WFD morphological identification vs environmental DNA comparison on the island of Mayotte (where the WFD applies) by the French ONEMA-AFB (Vasselon et al., 2017a), international funding or transnational programmes for such studies in the "borderland" (sensu Kelly et al., 2015) between research and management are of central importance. Many of the challenges we have highlighted are now being addressed by networks of working groups (see Fig. 5) mostly 
using individual, institutional, national or European research funds, and other research groups elsewhere in the world (Hajibabaei et al., 2016). One of the intended outputs is a streamlined array of good-practice strategies from sampling to assessment, but further international programmes of research funding agencies will need to prioritise cross-method comparisons to take these forward into a legally robust, backward-compatible toolkit ready for future monitoring programmes starting after the end-points of MSFD and WFD in 2020 and 2027, respectively. Genetic tools hold the promise to make aquatic biomonitoring better, cheaper (but see Section 4.5) and more reliable (or, at least, as reliable for a comparable cost), but the support mechanisms to develop them across sectors and countries need to be implemented as soon as possible to ensure early adoption of good-practice approaches.

\subsection{The Importance of Transdisciplinary Dialogue}

It has never been an easy task to link science, industry, decision making and practice, especially due to different motivations and organisational mechanisms that govern these sectors, but also because of the insular traditions that kept them "independent" from each other (Friberg et al., 2011). As a result, dissemination strategies are most often focussing on single sectors, and rarely cross their borders. This may explain why despite significant progress in academic development and application of molecular tools for bioassessment (see sections above), it appears that there is still limited immediate demand for biomonitoring 2.0 by regulatory agencies and little awareness in the general public. At the same time, and from a policy maker's and water manager's perspective, there is increased acknowledgement that scientific findings and recommendations on practical aspects such as biomonitoring must be communicated and disseminated outside existing research networks, if scientists want these methods to become attractive more rapidly beyond the strictly academic sphere (Mea et al., 2016). Most large-scale research funding now has to show effective dissemination and exploitation strategies for communicating project activities and results to external stakeholders, enterprises and the general public, thereby linking academic and public sectors (Elliott et al., 2017). Despite these tasks being seemingly straightforward and intuitive, as well as a required deliverable from grant funding, they are embedded within formal academic training, so the urgent need for filling these knowledge gaps is still largely unrecognised outside academia. 
Communication of new approaches and methods in next-generation biomonitoring needs to primarily target policy makers and water managers at the water basin scale, explaining the efficiency, cost-effectiveness and compatibility of the new approaches. However, the public also needs to be aware of and therefore informed on the potential benefits of these methods for environmental protection and management. There is still a long way to go, as even an established intersectoral communication strategy does not automatically lead to implementation of the new methods, especially since it also needs an appropriately skilled workforce. Globally, it is now an important task to find ways to efficiently inform users and providers of routine biomonitoring of new genetic techniques (even at a basic but unified level), for example, by using Massive Open Online Courses (MOOCs) or sharing tutorials on this topic, which could for instance be disseminated by high-level authorities coordinating biomonitoring implementation, or leading national agencies involved in routine biomonitoring (Lowndes et al., 2017). Fostering an informed start-up environment among the upcoming generation of monitoring specialists may better link to industry. Here, academia plays a central role as it should provide training via specialised master courses, PhDs and postdocs.

\section{THE AIM OF DNAqua-Net}

All of these challenges and opportunities for developing the next generation of aquatic biomonitoring provided the impetus for the EU COST Action DNAqua-Net (CA15219), established in November 2016 under the COST (Co-Operation in Science and Technology) programme. The principal goal of the network that runs until October 2020 is to connect the relevant actors working on aquatic biomonitoring and DNA-based tool development to develop concepts and a roadmap for the application of new genetic tools in aquatic bioassessment programmes in Europe and beyond (Leese et al., 2016; see http://DNAqua.Net). The international consortium consists of 39 countries of the expanded European Union (i.e. EU member states, near neighbour countries and Israel) and eight international partner countries (i.e. Australia, Brazil, Canada, Iran, New Zealand, Russia, United States of America and Uruguay), represented by $\sim 370$ participants one year after the network launch. DNAqua-Net's five working groups (WGs in Fig. 4) are targeting the further development and curation of aquatic DNA barcode reference libraries (WG1), the 
adjustment and development of (ecogenomic) biotic indices and metrics (WG2), the optimisation, development and evaluation of field and lab protocols for DNA-based biomonitoring (WG3), the storage and analysis of "big biodiversity data" (WG4) and the legal implementation and other relevant legislative issues (WG5). The main idea is to connect people and expertise and not to fund primary research. Furthermore, there is a strong focus on the integration of stakeholders from the outset and the promotion of early-career investigators to develop the human resource capacity needed for the next generation for researchers and practitioners. Since August 2017, $10 \%$ of all participants are active stakeholders and $35 \%$ of the management committee are junior researchers. Moreover, several small and medium enterprises represented in the consortium, or people working in private structures for the collection of the biodiversity data further foster knowledge transfer from academia into practice, e.g., by training schools that are organised (e.g. 2018 on DNA-based biomonitoring for the fourth Joint Danube Survey, JDS4). A further step towards inclusion of a broader academic and nonacademic audience is the establishment of specialised forums explicitly addressing regulator needs, such as the open access Metabarcoding and Metagenomics journal (Leese et al., 2017) launched by DNAqua-Net members and Pensoft (Ltd.) with specific article formats such as applied studies (e.g. Theissinger et al., 2018), biomonitoring schemes, primer/probe validation for bioassessment (e.g. Vamos et al., 2017) and DNA barcode reference libraries. Moreover, recommendations of DNAqua-Net Working Groups will be made public via announcements on the website (http://DNAqua.Net), publications in relevant stakeholder and water manager journals (e.g. Leese et al., 2017), during stakeholder meetings and workshops (e.g. Norman-Network meeting 2017, Joint Danube Survey meeting 2017, Rhine Commission meeting 2017) or by special invitations to targeted conferences (DNAqua-Net conference in March 2017, Essen, Germany) or via special sessions (e.g. 10th European Symposium for Freshwater Sciences, Czech Republic and 7th International Barcode of Life Conference, South Africa), to raise awareness for the importance of upgraded bioassessment schemes. In particular, waterresource management stakeholders will profit from information generated in DNAqua-Net and will be targeted via suitable channels, e.g., (i) specific journals addressing the audience involved in all sorts of water related issues (e.g. Leese et al., 2017), (ii) workshops and (iii) specialised dissemination materials. 


\subsection{Networks Among Countries, Across Generations and Disciplines}

In some countries not bound by EU legislation, in particular in southeast Europe, budget limitations as well as the lack of support by stakeholders favour temporally restricted studies over standardised and continuous (bio)surveillance. When considering the development of the next generation of genetic biomonitoring tools, an obvious challenge is the unequal access of countries to information and technology. Advanced genomic analyses (e.g. HTS) are still underutilised in developing countries with low $\mathrm{R} \& \mathrm{D}$ spending due to insufficient national funding, limited access to international grants, newest biotechnological infrastructures and training programmes, up-to-date literature and high costs of licensed analysis tools (Helmy et al., 2016). Network programmes such as the COST Action $D N A q u a-N e t$ are of vital importance in building permanent cooperation platforms to help overcome knowledge or framework gaps between countries and to develop harmonised transnational approaches to common biomonitoring issues. The diversity of countries participating in DNAqua-Net ranges from those with strong government-stakeholders-academia links to those that are far less research intensive (i.e. inclusiveness target countries; ITCs). This provides added value in form of combining different experiences and practices and gives participants that would otherwise be excluded access to these emerging technologies. While this has little disadvantages to countries with strong research infrastructure, it has significant advantages to the less research-intensive ITCs. Capacity building in the field of biomonitoring in ITCs is further enhanced through short-term scientific missions implemented within COST programmes that offer a possibility to early-career investigators from ITCs to gain practical experience in a given field of action, to increase their visibility in the broader scientific community and to establish international cooperation networks. In the year 2017, 10 such multinational exchange programmes have been successfully conducted during the launch phase of DNAqua-Net. DNAqua-Net has nonEuropean countries (Canada, USA) as partners in the network and as official "Management Committee observers" included from the very beginning. Other non-European countries have since then joined in, making DNAqua-Net a global network to develop DNA-based biomonitoring concepts for aquatic ecosystems.

Integration of the novel DNA-based or other advanced tools into current and future bioassessment workflows requires strong and sustained 
interdisciplinary dialogue among academics, regulators and industry, especially since the technological advancement is fast. Collaborative networks planning to distil and funnel scientific progress into the current regulatory framework must therefore offer to participate in the implementation process, taking into account potential inertia at the national and regional levels of organisation. In Europe, the creation of such networks is currently fostered by, e.g., large international COST Actions and the Joint Programming Initiative knowledge hubs. In the context of aquatic bioassessment in Europe, facilitation of uptake of new methods requires dialogue with the relevant organisations of the regulatory framework (e.g. ECOSTAT for the WFD and Directorate-General for the Environment, http://ec. europa.eu/dgs/environment/). Thus, interdisciplinary networks such as the COST Action DNAqua-Net and also Joint Programming Initiative knowledge hubs link academics with regulators, industry and policy makers but are short-lived in terms of funding and infrastructure (i.e. 4 years for COST Actions and typically 3 years for Joint Programming Initiative knowledge hubs). Another prerequisite for the uptake of novel methods is that these become mature enough to be processed by the European Committee for Standardization (CEN, http://www.cen.eu), either into standards or through the modification of existing standards. Since method integration into European standards is a slow and separate process, it usually extends beyond the lifespan of ongoing scientific networks dedicated to this subject. Therefore, networks can often only lay the foundation for future consideration of mature methods into standards and update into legal frameworks such as the European Directives. However, in the case of DNAqua-Net, network members and members of CEN Working Group 2 of Technical Committee 230 on "Biological methods" have agreed upon the need for a new permanent CEN working group that will pursue aquatic DNA-based method standardisation in the future.

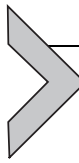

\section{NEXT-GENERATION BIOMONITORING OPENS NEW DOORS}

Aside from the advantages that new methods offer to current biomonitoring programmes, there are additional potentially ground-breaking opportunities: the amount and type of data will allow researchers to address fundamental ecological questions in unprecedented ways. Many of the core questions in ecology are still centred around how many and which species coexist in given ecosystems, how they shape ecosystem processes and what are the spatial and temporal scales of these dynamics. To date most 
experimental ecological work has focussed on small scales and short time spans, while many of the major questions related to large scales and long time spans have been left unanswered. Such formerly data-restricted research is now being transformed and "big data", as opposed to too little data, are the growing challenge that will face the next generations of ecologists (Keck et al., 2017). Metabarcoding and metagenomics, potentially in combination with remote sensing and new machine learning/"big data" algorithms, offer novel ways of providing new and fundamental insight into ecological dynamics from local to global scales and across organisational levels (Bohan et al., 2017; Bush et al., 2017). For example, DNA-based methods were recently used to show that remarkably similar ecosystem functions can be observed irrespective of high taxonomic turnover in bacterial and archaeal community composition in the "miniature aquatic ecosystems" maintained in bromeliad plants (Louca et al., 2016). Another recent example shows that multitrophic diversity scales highly nonlinearly across space (Schuldt et al., 2015), and yet another shows how gene-toecosystem impacts of a pesticide spill can be traced through from individual functional genes to the entire food web (Andújar et al., 2017). One of the most fascinating prospects is the potential use of sequence data to reconstruct complete food webs and species associations (Bohan et al., 2017; MoruetaHolme et al., 2016; Roslin and Majaneva, 2016) and to measure as well as forecast ecosystem processes by linking them to the measured expression of functional genes (Jackson et al., 2016b). An important step towards this goal is to stratify sampling campaigns at orders of magnitudes higher (across space and time) than in the past, as opposed to only aiming to maximise the taxonomic resolution and speed as part of the available sampling and monitoring campaigns. Thereby, an involvement of scientists early on in the planning of applied (e)DNA studies is crucial to maximise these potential synergies, especially as many ecologists are still unaware of the full potential of these tools, and the molecular scientists may likewise not appreciate the bigger questions that can be asked using their approaches. In addition, ecological concepts and models will increasingly need to be adapted in ways that allow the use of nontraditional abundance/biomass estimates (Choo et al., 2017) or even presence/absence data, at least until the issue of molecular based quantification of these parameters has been resolved. It now seems inevitable that ecology will make huge leaps forward with respect to predictability and causality, in ways that are comparable to the rate and scale of advancements made in climate science over recent decades. A central goal of DNAqua-Net and parallel research programmes is to stimulate such a process and connect research and applied communities alike. 


\section{ACKNOWLEDGEMENTS}

This chapter is based upon work from COST Action DNAqua-Net (CA15219), supported by the COST (European Cooperation in Science and Technology) programme. We thank all DNAqua-Net members for their input and in particular Donald Baird, Andrew Mahon, Kristy Deiner, Eric Stein, Roger Sweeting and Mehrdad Hajibabaei for helpful discussions. Thanks also to Slavena Peneva (Pensoft Publishers) for bringing the figures into shape. We are extremely thankful to Guy Woodward for meticulously reviewing and critically commenting on this manuscript and thereby improving it substantially in terms of content and style. Furthermore, we thank Sarah Kückmann for administrative help as well as Mafalda Quintas and Rose Cruz Santos of the EU COST office (Brussels) for their permanent support.

\section{REFERENCES}

Amir, A., Mcdonald, D., Navas-Molina, J.A., Kopylova, E., Morton, J.T., Zech Xu, Z., Kightley, E.P., Thompson, L.R., Hyde, E.R., Gonzalez, A., Knight, R., 2017. Deblur rapidly resolves single-nucleotide community sequence patterns. mSystems 2, e00191-16.

Andújar, C., Arribas, P., Gray, C., Bruce, C., Woodward, G., Yu, D.W., Vogler, A.P., 2017. Metabarcoding of freshwater invertebrates to detect the effects of a pesticide spill. Mol. Ecol. 1-21. https://doi.org/10.1111/mec.14410.

Apothéloz-Perret-Gentil, L., Cordonier, A., Straub, F., Iseli, J., Esling, P., Pawlowski, J., 2017. Taxonomy-free molecular diatom index for high-throughput eDNA biomonitoring. Mol. Ecol. Resour. 17, 1231-1242.

Arribas, P., Andujar, C., Hopkins, K., Shepherd, M., Vogler, A.P., 2016. Metabarcoding and mitochondrial metagenomics of endogean arthropods to unveil the mesofauna of the soil. Methods Ecol. Evol. 7, 1071-1081.

Aylagas, E., Borja, A., Rodriguez-Ezpeleta, N., 2014. Environmental status assessment using DNA metabarcoding: towards a genetics based Marine Biotic Index (gAMBI). PLoS One 9, e90529.

Baird, D.J., Hajibabaei, M., 2012. Biomonitoring 2.0: a new paradigm in ecosystem assessment made possible by next-generation DNA sequencing. Mol. Ecol. 21, 2039-2044.

Bergsten, J., Bilton, D.T., Fujisawa, T., Elliott, M., Monaghan, M.T., Balke, M., Hendrich, L., Geijer, J., Herrmann, J., Foster, G.N., Ribera, I., Nilsson, A.N., Barraclough, T.G., Vogler, A.P., 2012. The effect of geographical scale of sampling on DNA barcoding. Syst. Biol. 61, 851-869.

Biggs, J., Ewald, N., Valentini, A., Gaboriaud, C., Dejean, T., Griffiths, R.A., Foster, J., Wilkinson, J.W., Arnell, A., Brotherton, P., Williams, P., Dunn, F., 2015. Using eDNA to develop a national citizen science-based monitoring programme for the great crested newt (Triturus cristatus). Biol. Conserv. 183, 19-28.

Bik, H.M., Porazinska, D.L., Creer, S., Caporaso, J.G., Knight, R., Thomas, W.K., 2012. Sequencing our way towards understanding global eukaryotic biodiversity. Trends Ecol. Evol. 27, 233-243.

Birk, S., Bonne, W., Borja, A., Brucet, S., Courrat, A., Poikane, S., Solimini, A., Van De Bund, W.V., Zampoukas, N., Hering, D., 2012. Three hundred ways to assess Europe's surface waters: an almost complete overview of biological methods to implement the Water Framework Directive. Ecol. Indic. 18, 31-41.

Bohan, D.A., Vacher, C., Tamaddoni-Nezhad, A., Raybould, A., Dumbrell, A.J., Woodward, G., 2017. Next-generation global biomonitoring: large-scale, automated reconstruction of ecological networks. Trends Ecol. Evol. 32, 477-487. 
Bohmann, K., Evans, A., Gilbert, M.T.P., Carvalho, G.R., Creer, S., Knapp, M., Yu, D.W., De Bruyn, M., 2014. Environmental DNA for wildlife biology and biodiversity monitoring. Trends Ecol. Evol. 29, 358-367.

Bont, R.D., 2015. Stations in the Field: A History of Place-Based Animal Research. University of Chicago Press, Chicago, pp. 1870-1930.

Borja, A., Elliott, M., Carstensen, J., Heiskanen, A.S., Van De Bund, W., 2010. Marine management - towards an integrated implementation of the European Marine Strategy Framework and the Water Framework Directives. Mar. Pollut. Bull. 60, 2175-2186.

Borja, A., Dauer, D.M., Gremare, A., 2012. The importance of setting targets and reference conditions in assessing marine ecosystem quality. Ecol. Indic. 12, 1-7.

Borja, A., Elliott, M., Andersen, J.H., Berg, T., Carstensen, J., Halpern, B.S., Heiskanen, A.S., Korpinen, S., Lowndes, J.S.S., Martin, G., Rodriguez-Ezpeleta, N., 2016. Overview of integrative assessment of marine systems: the ecosystem approach in practice. Front. Mar. Sci. 3, 20.

Bourlat, S.J., Borja, A., Gilbert, J., Taylor, M.I., Davies, N., Weisberg, S.B., Griffith, J.F., Lettieri, T., Field, D., Benzie, J., Glockner, F.O., Rodriguez-Ezpeleta, N., Faith, D.P., Bean, T.P., Obst, M., 2013. Genomics in marine monitoring: new opportunities for assessing marine health status. Mar. Pollut. Bull. 74, 19-31.

Bush, A., Sollmann, R., Wilting, A., Bohmann, K., Cole, B., Balzter, H., Martius, C., Zlinszky, A., Calvignac-Spencer, S., Cobbold, C.A., Dawson, T.P., Emerson, B.C., Ferrier, S., Gilbert, M.T.P., Herold, M., Jones, L., Leendertz, F.H., Matthews, L., Millington, J.D.A., Olson, J.R., Ovaskainen, O., Raffaelli, D., Reeve, R., Rödel, M.-O., Rodgers, T.W., Snape, S., Visseren-Hamakers, I., Vogler, A.P., White, P.C.L., Wooster, M.J., Yu, D.W., 2017. Connecting Earth observation to high-throughput biodiversity data. Nat. Ecol. Evol. 1, 0176.

Butcher, R.W., 1946. The biological detection of pollution. J. Inst. Sew. Purif. 2, 92-97.

Callahan, B.J., Mcmurdie, P.J., Rosen, M.J., Han, A.W., Johnson, A.J.A., Holmes, S.P., 2016. DADA2: high-resolution sample inference from Illumina amplicon data. Nat. Methods 13, 581-583.

Callahan, B.J., Mcmurdie, P.J., Holmes, S.P., 2017. Exact sequence variants should replace operational taxonomic units in marker-gene data analysis. ISME J 11, 2639-2643.

CBD (Convention on Biological Diversity), 1992. 5 June 1992, 1760 UNTS 79; 31 ILM 818. Entered into force 29 Dec 1993. United Nations, New York, NY.

Choo, L.Q., Crampton-Platt, A., Vogler, A.P., 2017. Shotgun mitogenomics across body size classes in a local assemblage of tropical Diptera: phylogeny, species diversity and mitochondrial abundance spectrum. Mol. Ecol. 26, 5086-5098.

Cicconardi, F., Borges, P.A.V., Strasberg, D., Oromi, P., Lopez, H., Perez-Delgado, A.J., Casquet, J., Caujape-Castells, J., Fernandez-Palacios, J.M., Thebaud, C., Emerson, B.C., 2017. MtDNA metagenomics reveals large-scale invasion of belowground arthropod communities by introduced species. Mol. Ecol. 26, 3104-3115.

Cohn, F., 1853. Über lebende Organismen im Trinkwasser. Günsberg's Z. Klin. Med. 4, 229-237.

Cordier, T., Esling, P., Lejzerowicz, F., Visco, J., Ouadahi, A., Martins, C., Cedhagen, T., Pawlowski, J., 2017. Predicting the ecological quality status of marine environments from eDNA metabarcoding data using supervised machine learning. Environ. Sci. Technol. 51, 9118-9126.

Couto, C.R.D., Jurelevicius, D.D., Alvarez, V.M., Van Elsas, J.D., Seldin, L., 2016. Response of the bacterial community in oil-contaminated marine water to the addition of chemical and biological dispersants. J. Environ. Manage. 184, 473-479.

Crampton-Platt, A., Yu, D.W., Zhou, X., Vogler, A.P., 2016. Mitochondrial metagenomics: letting the genes out of the bottle. Gigascience 5, 15. 
Creer, S., Deiner, K., Frey, S., Porazinska, D., Taberlet, P., Thomas, W.K., Potter, C., Bik, H.M., 2016. The ecologist's field guide to sequence-based identification of biodiversity. Methods Ecol. Evol. 7, 1008-1018.

de Vargas, C., Audic, S., Henry, N., Decelle, J., Mahe, F., Logares, R., Lara, E., Berney, C., Le Bescot, N., Probert, I., Carmichael, M., Poulain, J., Romac, S., Colin, S., Aury, J.M., Bittner, L., Chaffron, S., Dunthorn, M., Engelen, S., Flegontova, O., Guidi, L., Horak, A., Jaillon, O., Lima-Mendez, G., Lukes, J., Malviya, S., Morard, R., Mulot, M., Scalco, E., Siano, R., Vincent, F., Zingone, A., Dimier, C., Picheral, M., Searson, S., Kandels-Lewis, S., Acinas, S.G., Bork, P., Bowler, C., Gorsky, G., Grimsley, N., Hingamp, P., Iudicone, D., Not, F., Ogata, H., Pesant, S., Raes, J., Sieracki, M.E., Speich, S., Stemmann, L., Sunagawa, S., Weissenbach, J., Wincker, P., Karsenti, E., Coordinators, T.O., 2015. Eukaryotic plankton diversity in the sunlit ocean. Science 348, 1261605-1/11.

Deiner, K., Fronhofer, E.A., Machler, E., Walser, J.C., Altermatt, F., 2016. Environmental DNA reveals that rivers are conveyer belts of biodiversity information. Nat. Commun. 7 , 12544.

Diaz, R.J., Solan, M., Valente, R.M., 2004. A review of approaches for classifying benthic habitats and evaluating habitat quality. J. Environ. Manage. 73, 165-181.

Dowle, E.J., Pochon, X., Banks, J.C., Shearer, K., Wood, S.A., 2016. Targeted gene enrichment and high-throughput sequencing for environmental biomonitoring: a case study using freshwater macroinvertebrates. Mol. Ecol. Resour. 16, 1240-1254.

Dudgeon, D., Arthington, A.H., Gessner, M.O., Kawabata, Z.I., Knowler, D.J., Leveque, C., Naiman, R.J., Prieur-Richard, A.H., Soto, D., Stiassny, M.L.J., Sullivan, C.A., 2006. Freshwater biodiversity: importance, threats, status and conservation challenges. Biol. Rev. 81, 163-182.

Egerton, F.N., 2014. History of ecological sciences, part 51: formalizing marine ecology, 1870s to 1920s. Bull. Ecol. Soc. Am. 95, 347-430.

Ekrem, T., Willassen, E., Stur, E., 2007. A comprehensive DNA sequence library is essential for identification with DNA barcodes. Mol. Phylogenet. Evol. 43, 530-542.

Elbrecht, V., Leese, F., 2015. Can DNA-based ecosystem assessments quantify species abundance? Testing primer bias and biomass - sequence relationships with an innovative metabarcoding protocol. PLoS One 10, e0130324.

Elbrecht, V., Leese, F., 2017. Validation and development of COI metabarcoding primers for freshwater macroinvertebrate bioassessment. Front. Environ. Sci. 5, 11.

Elbrecht, V., Peinert, B., Leese, F., 2017a. Sorting things out: assessing effects of unequal specimen biomass on DNA metabarcoding. Ecol. Evol. 7, 6918-6926.

Elbrecht, V., Vamos, E.E., Meissner, K., Aroviita, J., Leese, F., Yu, D., 2017b. Assessing strengths and weaknesses of DNA metabarcoding-based macroinvertebrate identification for routine stream monitoring. Methods Ecol. Evol. 8, 1265-1275.

Elliott, M., Snoeijs-Leijonmalm, P., Barnard, S., 2017. 'The dissemination diamond' and paradoxes of science-to-science and science-to-policy communication: lessons from large marine research programmes. Mar. Pollut. Bull. 125, 1-3.

Eren, A.M., Vineis, J.H., Morrison, H.G., Sogin, M.L., 2013. A filtering method to generate hgh quality short reads using Illumina paired-end technology. PLoS One 8, e66643.

Friberg, N., Bonada, N., Bradley, D.C., Dunbar, M.J., Edwards, F.K., Grey, J., Hayes, R.B., Hildrew, A.G., Lamouroux, N., Trimmer, M., Woodward, G., 2011. Biomonitoring of human impacts in freshwater ecosystems: the good, the bad and the ugly. Adv. Ecol. Res. 44 (44), 1-68.

Gibson, J.F., Shokralla, S., Curry, C., Baird, D.J., Monk, W.A., King, I., Hajibabaei, M., 2015. Large-scale biomonitoring of remote and threatened ecosystems via highthroughput sequencing. PLoS One 10, e0138432. 
Gray, J.S., Elliott, M., 2009. Ecology of Marine Sediments. From Science to Management. Oxford University Press, New York.

Haase, P., Pauls, S.U., Schindehutte, K., Sundermann, A., 2010. First audit of macroinvertebrate samples from an EU Water Framework Directive monitoring program: human error greatly lowers precision of assessment results. J. N. Am. Benthol. Soc. 29, 1279-1291.

Hajibabaei, M., Shokralla, S., Zhou, X., Singer, G.A., Baird, D.J., 2011. Environmental barcoding: a next-generation sequencing approach for biomonitoring applications using river benthos. PLoS One 6, e17497.

Hajibabaei, M., Baird, D.J., Fahner, N.A., Beiko, R., Golding, G.B., 2016. A new way to contemplate Darwin's tangled bank: how DNA barcodes are reconnecting biodiversity science and biomonitoring. Philos. Trans. R. Soc. Lond. B Biol. Sci. 371, 20150330.

Hawkins, C.P., Norris, R.H., Hogue, J.N., Feminella, J.W., 2000. Development and evaluation of predictive models for measuring the biological integrity of streams. Ecol. Appl. $10,1456-1477$.

Hebert, P.D., Cywinska, A., Ball, S.L., 2003. Biological identifications through DNA barcodes. Proc. Biol. Sci. 270, 313-321.

Helmy, M., Awad, M., Mosa, K.A., 2016. Limited resources of genome sequencing in developing countries: challenges and solutions. Appl. Transl. Genom. 9, 15-19.

Hering, D., Johnson, R.K., Kramm, S., Schmutz, S., Szoszkiewicz, K., Verdonschot, P.F.M., 2006. Assessment of European rivers with diatoms, macrophytes, invertebrates and fish: a comparative metric-based analysis of organism response to stress. Freshw. Biol. 51, 1757-1785.

Hering, D., Carvalho, L., Argillier, C., Beklioglu, M., Borja, A., Cardoso, A.C., Duel, H., Ferreira, T., Globevnik, L., Hanganu, J., Hellsten, S., Jeppesen, E., Kodes, V., Solheim, A.L., Noges, T., Ormerod, S., Panagopoulos, Y., Schmutz, S., Venohr, M., Birk, S., 2015. Managing aquatic ecosystems and water resources under multiple stress - an introduction to the MARS project. Sci. Total Environ. 503, 10-21.

Jackson, M.C., Loewen, C.J.G., Vinebrooke, R.D., Chimimba, C.T., 2016a. Net effects of multiple stressors in freshwater ecosystems: a meta-analysis. Glob. Chang. Biol. 22, 180-189.

Jackson, M.C., Weyl, O.L.F., Altermatt, F., Durance, I., Friberg, N., Dumbrell, A.J., Piggott, J.J., Tiegs, S.D., Tockner, K., Krug, C.B., Leadley, P.W., Woodward, G., 2016b. Recommendations for the next generation of global freshwater biological monitoring tools. Adv. Ecol. Res. 55, 615-636.

Jerde, C.L., Chadderton, W.L., Mahon, A.R., Renshaw, M.A., Corush, J., Budny, M.L., Mysorekar, S., Lodge, D.M., 2013. Detection of Asian carp DNA as part of a Great Lakes basin-wide surveillance program. Can. J. Fish. Aquat. Sci. 70, 522-526.

Jörger, K.M., Schrödl, M., 2013. How to describe a cryptic species? Practical challenges of molecular taxonomy. Front. Zool. 10, 59.

Karr, J.R., 1991. Biological integrity - a long-neglected aspect of water-resource management. Ecol. Appl. 1, 66-84.

Keck, F., Rimet, F., Franc, A., Bouchez, A., 2016. Phylogenetic signal in diatom ecology: perspectives for aquatic ecosystems biomonitoring. Ecol. Appl. 26, 861-872.

Keck, F., Vasselon, V., Tapolczai, K., Rimet, F., Bouchez, A., 2017. Freshwater biomonitoring in the Information age. Front. Ecol. Environ. 15, 266-274.

Kelly, M.G., Schneider, S.C., King, L., 2015. Customs, habits, and traditions: the role of nonscientific factors in the development of ecological assessment methods. Wiley Inter. Rev. Water 2, 159-165.

Kermarrec, L., Franc, A., Rimet, F., Chaumeil, P., Humbert, J.F., Bouchez, A., 2013. Nextgeneration sequencing to inventory taxonomic diversity in eukaryotic communities: a test for freshwater diatoms. Mol. Ecol. Resour. 13, 607-619. 
Kolkwitz, R., Marsson, M., 1902. Grundsätze für die biologische Beurteilung des Wassers nach seiner Flora und Fauna. Mitt. Prüfungsanst. Wasserversorg. Abwasserbeseit. 1, 33-72.

Kolkwitz, R., Marsson, M., 1908. Ökologie der pflanzlichen Saprobien. Ber. Deutsch. Bot. Ges. 26a, 505-519.

Kolkwitz, R., Marsson, M., 1909. Ökologie der tierischen Saprobien. Int. Rev. Gesamten Hydrobiol. 2, 126-152.

Krehenwinkel, H., Wolf, M., Lim, J.Y., Rominger, A.J., Simison, W.B., Gillespie, R.G., 2017. Estimating and mitigating amplification bias in qualitative and quantitative arthropod metabarcoding. Sci. Rep. 7, 17668.

Lange-Bertalot, H., Steindorf, A., 1996. Rote Liste der limnischen Kieselalgen (Bacillariophyceae) Deutschlands. Schrift. Vegetationsk 28, 633-677.

Leese, F., Altermatt, F., Bouchez, A., Ekrem, T., Hering, D., Meissner, K., Mergen, P., Pawlowski, J., Piggott, J., Rimet, F., Steinke, D., Taberlet, P., Weigand, A., Abarenkov, K., Beja, P., Bervoets, L., Björnsdóttir, S., Boets, P., Boggero, A., Bones, A., Borja, Á., Bruce, K., Bursić, V., Carlsson, J., Čiampor, F., ČiamporováZatovičová, Z., Coissac, E., Costa, F., Costache, M., Creer, S., Csabai, Z., Deiner, K., DelValls, Á., Drakare, S., Duarte, S., Eleršek, T., Fazi, S., Fišer, C., Flot, J., Fonseca, V., Fontaneto, D., Grabowski, M., Graf, W., Guðbrandsson, J., Hellström, M., Hershkovitz, Y., Hollingsworth, P., Japoshvili, B., Jones, J., Kahlert, M., Kalamujic Stroil, B., Kasapidis, P., Kelly, M., Kelly-Quinn, M., Keskin, E., Kõljalg, U., Ljubešić, Z., Maček, I., Mächler, E., Mahon, A., Marečková, M., Mejdandzic, M., Mircheva, G., Montagna, M., Moritz, C., Mulk, V., Naumoski, A., Navodaru, I., Padisák, J., Pálsson, S., Panksep, K., Penev, L., Petrusek, A., Pfannkuchen, M., Primmer, C., Rinkevich, B., Rotter, A., Schmidt-Kloiber, A., Segurado, P., Speksnijder, A., Stoev, P., Strand, M., Šulčius, S., Sundberg, P., Traugott, M., Tsigenopoulos, C., Turon, X., Valentini, A., van der Hoorn, B., Várbíró, G., Vasquez Hadjilyra, M., Viguri, J., Vitonyte, I., Vogler, A., Vrålstad, T., Wägele, W., Wenne, R., Winding, A., Woodward, G., Zegura, B., Zimmermann, J., 2016. DNAqua-Net: developing new genetic tools for bioassessment and monitoring of aquatic ecosystems in Europe. Res. Ideas Outcomes 2, e11321.

Leese, F., Hering, D., Wägele, J.-W., 2017. Potenzial genetischer Methoden für das Biomonitoring der Wasserrahmenrichtlinie. Wasserwirtschaft (7-8), 49-53.

Lejzerowicz, F., Esling, P., Pillet, L., Wilding, T.A., Black, K.D., Pawlowski, J., 2015. Highthroughput sequencing and morphology perform equally well for benthic monitoring of marine ecosystems. Sci. Rep. 5, 13932.

Lin, X.-L., Stur, E., Ekrem, T., 2017. DNA barcodes and morphology reveal unrecognized species in Chironomidae (Diptera). Insect Syst. Evol. https://doi.org/10.1163/ $1876312 X-00002172$.

Louca, S., Jacques, S.M.S., Pires, A.P.F., Leal, J.S., Srivastava, D.S., Parfrey, L.W., Farjalla, V.F., Doebeli, M., 2016. High taxonomic variability despite stable functional structure across microbial communities. Nat. Ecol. Evol. 1, 15.

Lowndes, J.S.S., Best, B.D., Scarborough, C., Afflerbach, J.C., Frazier, M.R., O’hara, C.C., Jiang, N., Halpern, B.S., 2017. Our path to better science in less time using open data science tools. Nat. Ecol. Evol. 1, 0160.

Macher, J.N., Salis, R.K., Blakemore, K.S., Tollrian, R., Matthaei, C.D., Leese, F., 2016. Multiple-stressor effects on stream invertebrates: DNA barcoding reveals contrasting responses of cryptic mayfly species. Ecol. Indic. 61, 159-169.

Macher, J.N., Zizka, V., Weigand, A.M., Leese, F., 2017. A simple centrifugation protocol for metagenomic studies increases mitochondrial DNA yield by two orders of magnitude. Methods Ecol. Evol. 1-5. 
Mächler, E., Deiner, K., Steinmann, P., Altermatt, F., 2014. Utility of environmental DNA for monitoring rare and indicator macroinvertebrate species. Freshw. Sci. 33, 1174-1183.

Mea, M., Newton, A., Uyarra, M.C., Alonso, C., Borja, A., 2016. From science to policy and society: enhancing the effectiveness of communication. Front. Mar. Sci. 3, 168.

Millennium Ecosystem Assessment, 2005. Ecosystems and Human Well-Being: Synthesis. Island Press, Washington, DC.

Morueta-Holme, N., Blonder, B., Sandel, B., Mcgill, B.J., Peet, R.K., Ott, J.E., Violle, C., Enquist, B.J., Jorgensen, P.M., Svenning, J.C., 2016. A network approach for inferring species associations from co-occurrence data. Ecography 39, 1139-1150.

Moss, D., Furse, M.T., Wright, J.F., Armitage, P.D., 1987. The prediction of the macroinvertebrate fauna of unpolluted running-water sites in great-Britain using environmental data. Freshw. Biol. 17, 41-52.

Mulder, C., Bennett, E.M., Bohan, D.A., Bonkowski, M., Carpenter, S.R., Chalmers, R., Cramer, W., Durance, I., Eisenhauer, N., Fontaine, C., Haughton, A.J., Hettelingh, J.P., Hines, J., Ibanez, S., Jeppesen, E., Krumins, J.A., Ma, A., Mancinelli, G., Massol, F., Mclaughlin, O., Naeem, S., Pascual, U., Penuelas, J., Pettorelli, N., Pocock, M.J.O., Raffaell, D., Rasmussen, J.J., Rusch, G.M., Scherber, C., Setala, H., Sutherland, W.J., Vacher, C., Voigt, W., Vonk, J.A., Wood, S.A., Woodward, G., 2015. 10 years later: revisiting priorities for science and society a decade after the millennium ecosystem assessment. Adv. Ecol. Res. 53, 1-53.

Oliveira, L.M., Knebelsberger, T., Landi, M., Soares, P., Raupach, M.J., Costa, F.O., 2016. Assembling and auditing a comprehensive DNA barcode reference library for European marine fishes. J. Fish Biol. 89, 2741-2754.

Pawlowski, J., Audic, S., Adl, S., Bass, D., Belbahri, L., Berney, C., Bowser, S.S., Cepicka, I., Decelle, J., Dunthorn, M., Fiore-Donno, A.M., Gile, G.H., Holzmann, M., Jahn, R., Jirku, M., Keeling, P.J., Kostka, M., Kudryavtsev, A., Lara, E., Lukes, J., Mann, D.G., Mitchell, E.a.D., Nitsche, F., Romeralo, M., Saunders, G.W., Simpson, A.G.B., Smirnov, A.V., Spouge, J.L., Stern, R.F., Stoeck, T., Zimmermann, J., Schindel, D., De Vargas, C., 2012. CBOL protist working group: barcoding eukaryotic richness beyond the animal, plant, and fungal kingdoms. PLoS Biol. 10, e1001419.

Pearson, T., Rosenberg, R., 1978. Macrobenthic succession in relation to organic enrichment and pollution of the marine environment. Oceanogr. Mar. Biol. Annu. Rev. 16, 229-311.

Pinol, J., Mir, G., Gomez-Polo, P., Agusti, N., 2015. Universal and blocking primer mismatches limit the use of high-throughput DNA sequencing for the quantitative metabarcoding of arthropods. Mol. Ecol. Resour. 15, 819-830.

Poikane, S., Zampoukas, N., Borja, A., Davies, S.P., Van De Bund, W., Birk, S., 2014. Intercalibration of aquatic ecological assessment methods in the European Union: lessons learned and way forward. Environ. Sci. Policy 44, 237-246.

Radom, M., Rybarczyk, A., Kottmann, R., Formanowicz, P., Szachniuk, M., Glockner, F.O., Rebholz-Schuhmann, D., Blazewicz, J., 2012. Poseidon: an information retrieval and extraction system for metagenomic marine science. Eco. Inform. 12, 10-15.

Rimet, F., Chaumeil, P., Keck, F., Kermarrec, L., Vasselon, V., Kahlert, M., Franc, A., Bouchez, A., 2016. R-Syst::diatom: an open-access and curated barcode database for diatoms and freshwater monitoring. Database 2016, baw016.

Rimet, F., Abarca, N., Bouchez, A., Kusber, W.-H., Jahn, R., Kahlert, M., Keck, F., Kelly, M.G., Mann, D.G., Piuz, A., Trobajo, R., Tapolczai, K., Vasselon, V., Zimmermann, J., 2018. The potential of high throughput sequencing (HTS) of natural samples as a source of primary taxonomic information for reference libraries of diatom barcodes. Fottea18/1. 
Roslin, T., Majaneva, S., 2016. The use of DNA barcodes in food web constructionterrestrial and aquatic ecologists unite!. Genome 59, 603-628.

Rosser, N., 2017. Shortcuts in biodiversity research: what determines the performance of higher taxa as surrogates for species? Ecol. Evol. 7, 2595-2603.

Schmidt-Kloiber, A., Hering, D., 2015. www.freshwaterecology.info-an online tool that unifies, standardises and codifies more than 20,000 European freshwater organisms and their ecological preferences. Ecol. Indic. 53, 271-282.

Schmidt-Kloiber, A., Nijboer, R., 2004. The effect of taxonomic resolution on the assessment of ecological water quality classes. Hydrobiologia 516, 269-283.

Schuldt, A., Wubet, T., Buscot, F., Staab, M., Assmann, T., Bohnke-Kammerlander, M., Both, S., Erfmeier, A., Klein, A.M., Ma, K.P., Pietsch, K., Schultze, S., Wirth, C., Zhang, J.Y., Zumstein, P., Bruelheide, H., 2015. Multitrophic diversity in a biodiverse forest is highly nonlinear across spatial scales. Nat. Commun. 6, 10169.

Shokralla, S., Gibson, J., King, I., Baird, D., Janzen, D., Hallwachs, W., Hajibabaei, M., 2016. Environmental DNA barcode sequence capture: targeted, PCR-free sequence capture for biodiversity analysis from bulk environmental samples. bioRxiv 087437 .

Sládeček, V., 1965. The future of the saprobity system. Hydrobiologia 25, 518-537.

Staats, M., Arulandhu, A.J., Gravendeel, B., Holst-Jensen, A., Scholtens, I., Peelen, T., Prins, T.W., Kok, E., 2016. Advances in DNA metabarcoding for food and wildlife forensic species identification. Anal. Bioanal. Chem. 408, 4615-4630.

Stein, E.D., White, B.P., Mazor, R.D., Jackson, J.K., Battle, J.M., Miller, P.E., Pilgrim, E.M., Sweeney, B.W., 2014. Does DNA barcoding improve performance of traditional stream bioassessment metrics? Freshw. Sci. 33, 302-311.

Stoeckle, M.Y., Soboleva, L., Charlop-Powers, Z., 2017. Aquatic environmental DNA detects seasonal fish abundance and habitat preference in an urban estuary. PLoS One 12, e0175186.

Taberlet, P., Coissac, E., Pompanon, F., Brochmann, C., Willerslev, E., 2012. Towards next-generation biodiversity assessment using DNA metabarcoding. Mol. Ecol. 21, 2045-2050.

Theissinger, K., Kästel, A., Elbrecht, V., Makkonen, J., Michiels, S., Schmidt, S., Allgeier, S., Leese, F., Brühl, C., 2018. Using DNA metabarcoding for assessing chironomid diversity and community change in mosquito controlled temporary wetlands. Metabarcoding Metagenomics 2, e21060.

Thomas, A.C., Deagle, B.E., Eveson, J.P., Harsch, C.H., Trites, A.W., 2016. Quantitative DNA metabarcoding: improved estimates of species proportional biomass using correction factors derived from control material. Mol. Ecol. Resour. 16, 714-726.

Thomsen, P.F., Kielgast, J., Iversen, L.L., Moller, P.R., Rasmussen, M., Willerslev, E., 2012. Detection of a diverse marine fish fauna using environmental DNA from seawater samples. PLoS One 7, e41732.

Townsend, C.R., Uhlmann, S.S., Matthaei, C.D., 2008. Individual and combined responses of stream ecosystems to multiple stressors. J. Appl. Ecol. 45, 1810-1819.

Tseng, C.H., Tang, S.L., 2014. Marine microbial metagenomics: from individual to the environment. Int. J. Mol. Sci. 15, 8878-8892.

United States, 1972. Federal Water Pollution Control Act Amendments of 1972. Pub.L. 92-500, October 18.

Valentini, A., Taberlet, P., Miaud, C., Civade, R., Herder, J., Thomsen, P.F., Bellemain, E., Besnard, A., Coissac, E., Boyer, F., Gaboriaud, C., Jean, P., Poulet, N., Roset, N., Copp, G.H., Geniez, P., Pont, D., Argillier, C., Baudoin, J.M., Peroux, T., Crivelli, A.J., Olivier, A., Acqueberge, M., Le Brun, M., Moller, P.R., Willerslev, E., Dejean, T., 2016. Next-generation monitoring of aquatic biodiversity using environmental DNA metabarcoding. Mol. Ecol. 25, 929-942. 
Vamos, E., Elbrecht, V., Leese, F., 2017. Short COI markers for freshwater macroinvertebrate metabarcoding. Metabarcoding Metagenomics 1, e14625.

Vasselon, V., Domaizon, I., Rimet, F., Kahlert, M., Bouchez, A., 2017a. Application of high-throughput sequencing (HTS) metabarcoding to diatom biomonitoring: do DNA extraction methods matter? Freshwater Science 36, 162-177.

Vasselon, V., Rimet, F., Tapolczai, K., Bouchez, A., 2017b. Assessing ecological status with diatoms DNA metabarcoding: scaling-up on a WFD monitoring network (Mayotte island, France). Ecol. Indic. 82, 1-12.

Vivien, R., Wyler, S., Lafont, M., Pawlowski, J., 2015. Molecular barcoding of aquatic oligochaetes: implications for biomonitoring. PLoS One 10, e0125485.

Vörösmarty, C.J., Mcintyre, P.B., Gessner, M.O., Dudgeon, D., Prusevich, A., Green, P., Glidden, S., Bunn, S.E., Sullivan, C.A., Liermann, C.R., Davies, P.M., 2010. Global threats to human water security and river biodiversity. Nature 467, 555-561.

Woodward, G., Gray, C., Baird, D.J., 2013. Biomonitoring for the 21st century: new perspectives in an age of globalisation and emerging environmental threats. Limnetica 32, 159-173.

WWF, 2016. Living Planet Report 2016. Risk and Resilience in a New Era. WWW International, Gland, Switzerland.

Yu, D.W., Ji, Y.Q., Emerson, B.C., Wang, X.Y., Ye, C.X., Yang, C.Y., Ding, Z.L., 2012. Biodiversity soup: metabarcoding of arthropods for rapid biodiversity assessment and biomonitoring. Methods Ecol. Evol. 3, 613-623.

Zhou, X., Li, Y.Y., Liu, S.L., Yang, Q., Su, X., Zhou, L.L., Tang, M., Fu, R.B., Li, J.G., Huang, Q.F., 2013. Ultra-deep sequencing enables high-fidelity recovery of biodiversity for bulk arthropod samples without PCR amplification. Gigascience 2, 4.

Zimmermann, J., Glöckner, G., Jahn, R., Enke, N., Gemeinholzer, B., 2015. Metabarcoding vs. morphological identification to assess diatom diversity in environmental studies. Mol. Ecol. Resour. 15, 526-542. 